\title{
The Impacts of Industrial and Entrepreneurial Work on Income and Health: Experimental Evidence from Ethiopia
}

\author{
By Christopher Blattman and Stefan Dercon*
}

\begin{abstract}
Working with five Ethiopian firms, we randomized applicants to an industrial job offer, an "entrepreneurship" program of $\$ 300$ plus business training, or control status. Industrial jobs offered more and steadier hours but low wages and risky conditions. The job offer doubled exposure to industrial work but, since most quit within months, had no impact on employment or income after a year. Applicants largely took industrial work to cope with adverse shocks. This exposure, meanwhile, significantly increased health problems. The entrepreneurship program raised earnings 33 percent and provided steadier hours. When barriers to self-employment were relieved, applicants preferred entrepreneurial to industrial labor. (JEL D22, I12, J23, J28, J81, L26, M53)
\end{abstract}

" The misery of being exploited by capitalists," the economist Joan Robinson famously remarked, "is nothing compared to the misery of not being exploited at all" $(1962,45)$. This reflects a common view that even low-wage industrial jobs provide poor people with higher and more stable earnings than their alternatives. 1$]$

Theoretically, there are several reasons why industrial work would pay a wage premium compared to informal work. Firms may pay efficiency wages or there may also be institutional and legislative sources, such as minimum wages, labor codes,

\footnotetext{
* Blattman: University of Chicago Harris Public Policy, 1155 E 60th Street, Chicago, IL 60637 and NBER (email: blattman@uchicago.edu); Dercon: Department of Economics, University of Oxford, Oxford OX1 2JD, UK, Centre for the Study of African Economies, and Blavatnik School of Government (email: stefan.dercon@qeh.ox.ac. uk).We thank the participating firms plus the Ethiopian Development Research Institute and Innovations for Poverty Action for field research. For comments we thank David Atkin, Abhijit Banerjee, Konrad Burchardi, Stefano Caria, Brandon de la Cuesta, Simon Franklin, Tim Harford, Macartan Humphreys, Supreet Kaur, Thomas Leavitt, Jeremy Magruder, Suresh Naidu, Paul Niehaus, Cristian Pop-Eleches, Dani Rodrik, Antoinette Schoar, Georgiy Syunyaev, Eric Verhoogen, Chris Woodruff, and seminar participants at Princeton University, Harvard Business School, Stanford University, Georgetown University, Johns Hopkins University SAIS, University of Oxford, University of Colorado Denver, CGD, DFID, and the 2015 NBER Summer Institute, 29th BREAD, 2015 CAPERS, and 2012 IGC Growth Week conferences. For funding we thank the Aspen ANDE group, the International Growth Center, the UK Department for International Development, the Templeton Foundation, and a Vanguard Charitable Trust. Natalie Carlson, Felipe Dizon, Courtney Han, Dawit Kebede, Sana Khan, Benjamin Morse, Richard Peck, Patryk Perkowski, Katherine Rodrigues, Joe St. Clair, and Nynne Warring provided research assistance.

Go to https://doi.org/10.1257/app.20170173 to visit the article page for additional materials and author disclosure statement(s) or to comment in the online discussion forum.

${ }^{1}$ We use the term "industrial" jobs to capture work in formal firms in manufacturing and high-intensity commercial agriculture, focusing on formal firms with 10 or more employees (i.e., excluding very small enterprises and workshops).
} 
or union bargaining. ${ }^{2}$ If so, the result is a dual or segmented labor market, in which those gaining industrial jobs earn rents while informal workers queue for those jobs. ${ }^{3}$

Empirically, a large body of observational evidence suggests that formal firms pay premium wages, especially large, foreign-owned or exporting firms. ${ }^{4}$ Women are commonly employed in low-skill firms, and there is observational evidence that working in textile factories or other export manufacturers raises women's status in the household, their quality of life, and the health of children. ${ }^{5}$ More anecdotally, it is also common to see long queues of applicants for factory jobs. By revealed preference, it would seem that workers who line up prefer these so-called sweatshops to their alternatives. ${ }^{6}$

Industrial jobs may be attractive only compared to poor people's largely informal alternatives. Summing up the case for sweatshops, Paul Krugman (1997) wrote, "the wages of those workers are shockingly low but nonetheless represent a vast improvement on their previous, less visible rural poverty." Even some opponents concede the point: a Scholars Against Sweatshop Labor statement (2001) admits that "after allowing for the frequent low wages and poor working conditions in these jobs, they are still generally superior to 'informal' employment in, for example, much of agriculture or urban street vending."

It is not clear, however, that wage premiums exist in general, or that steady employment makes up for the disamenities of industrial work. Some would argue that factory jobs, much like fast food positions, are no better or worse than other low-skill alternatives, such as agriculture or street vending. In standard theories of competitive markets, factor prices are equalized across sectors and firms. If unskilled and interchangeable, poor workers will be paid their low reservation wage. In this case, any queues outside of factories simply reflect normal search activities, and any formal sector wage premiums in the observational data reflect unobserved heterogeneity. 7

A more pessimistic view is that workers make poorly informed or present-biased decisions that sacrifice health or schooling, reducing long-run earnings potential. Looking at the rise of Mexican maquiladoras, for instance, Atkin (2012) observed that as firms and wage opportunities grew, young adults dropped out of high school to take the job, sacrificing a large amount of long-run earnings-a sacrifice inconsistent with even fairly high discount rates. New industries may also pose health risks that neither the firm nor worker fully understands.

\footnotetext{
${ }^{2}$ For examples, see Katz et al. (1989) and Akerlof and Yellen (1986) on efficiency wages, and Card (1996) on unions.

${ }^{3}$ Lewis (1954), Harris and Todaro (1970), and Fields (1975).

${ }^{4}$ For Mexico, see Bernard, Robertson, and Schott (2010); Verhoogen (2008); and for Africa, see Söderbom and Teal (2004); El Badaoui, Strobl, and Walsh (2008). Plant-level data show that large and foreign firms pay higher wages than smaller or domestically-owned ones (see Aitken, Harrison, and Lipsey 1996 for Venezuela and Mexico; Lipsey and Sjöholm 2004 for Indonesia; and Strobl and Thornton 2004 for five African countries). The correlation tends to remain but decreases when firm and worker characteristics are taken into account.

${ }^{5}$ Kabeer (2000) and Hewett and Amin (2000) provide evidence that working in textiles factories is associated with higher female status and quality of life. Atkin (2009) finds that Mexican women in export manufacturing increase their incomes, have more household bargaining power, and have taller children. Getahun and Villanger (2016) finds that flower farm work for poor rural women in Ethiopia increases their bargaining power.

6 "Sweatshop" jobs usually imply low wages, long hours, and unpleasant or hazardous working conditions. The firms in this paper arguably fit this broad definition, but since this is a subjective judgment, we refer to them as low-skill industrial jobs.

${ }^{7}$ For instance, firms may screen, select, and retain suitable workers that, to researchers, appear observationally equivalent (Rosenzweig 1988).
} 
In the long run, a rising industrial sector should raise demand for labor and thus improve wages and working conditions across the economy. But at the early stages of industrialization (before firms face tighter labor supply and must compete for qualified workers), it is unclear what opportunities and risks industrial jobs offer to workers relative to their informal opportunities.

This paper uses a case study and small-scale experiment in Ethiopia to investigate a set of questions: What are the relative qualities of informal and industrial work at this early stage of industrialization? Are there benefits or risks to the choice of one occupation over the other? And how does the quality of self-employment options affect this occupational choice?

We expected industrial jobs to be desirable and provide at a minimum more steady incomes, and possibly even some form of rents. Instead, we found that jobs in these firms look much more like fast food positions, and are not that desirable. If anything, they are undesirable and risky to people's health. Meanwhile, informal opportunities over time proved to be much better than we anticipated.

We follow a panel of nearly 1,000 applicants to entry-level jobs in 5 industrial firms in different parts of Ethiopia, reporting results over the first year of the study. We randomly assigned roughly a third of the applicants to a job offer, a third to a control group, and a third to an entrepreneurship program intended to improve their informal employment opportunities. A wave of "entrepreneurship" and "social protection" programs have increased poor people's incomes by giving them cash, livestock, skills, and other inputs into self-employment. These inputs relieve binding constraints and help the poor expand informal self-employment and raise their earnings (Banerjee and Duflo 2011, Blattman and Ralston 2015). Our program provided 5 days of business training and planning, followed by a $\$ 300$ grant (about $\$ 1,030$ in purchasing power parity, or PPP) 8

Ethiopia is a growing export hub in horticulture, textiles, and leather, and although the economy is moving in fits and starts through the early stages of industrialization, Ethiopia has been touted as one of "China's successors" in light manufacturing (e.g., NPR 2014). We approached hundreds of firms about the experiment. A majority were willing to participate in the study, but only a handful were eligible in the sense of hiring dozens of low-skilled workers at one time. In the end, we worked with five firms: a water bottling plant, a vegetable farm, a flower farm, a shoe manufacturer, and a textile and garment factory.

The people applying to these low-skill, entry-level jobs were generally unemployed but educated young adults, mainly women, who lived nearby the firms. Most had had no work in at least a month, and outside the factories most local work opportunities were informal.

The comparison between the job offer and control arms indicates how the industrial job compares to the workers' typical alternatives. The entrepreneurship arm, meanwhile, was designed to allow us to compare industrial work to the income trajectory, health, and other dimensions of better informal employment. ${ }^{9}$ The point

\footnotetext{
${ }^{8}$ This conversion is based on 2011 International Comparison Program data from the World Bank.

${ }^{9}$ Industry could have broader impacts that this design will not capture, such as incentives for prospective employees to gain education. Heath and Mobarak (2014) show that growth in the Bangladeshi textile industry
} 
is not to juxtapose a grant against a job (since a grant is unlikely to be a worker's counterfactual), but rather simulate self-employment opportunities under reduced capital constraints.

There are limits to what we can learn from five firms. Yet the same is true of any single program evaluation. Our results speak to low-skill light industry in contexts where workers are effectively disposable to firms. This is a common feature of light manufacturing and agribusiness in Ethiopia, and we discuss how our results are consistent with patterns in more representative panels of young, unskilled Ethiopian workers and job searchers, plus (to some extent) early and middle industrialization in the United States, Europe, and Asia.

Besides a randomized design, this situation also offers the opportunity to measure a range of outcomes over time, including physical and mental health. Previous studies have had larger samples but have relied on a narrow set of outcomes. Hence, the health and other nonpecuniary consequences of different occupations is not known.

Beforehand, we expected the offer of an industrial job not only to end a potentially lengthy unemployment spell, but also to increase the probability that these young people took permanent employment in the industrial sector. We also expected that unsuccessful applicants could still get work in industry, of course, but to the extent these jobs were scarce, or to the extent other informal opportunities could arise before the next industrial job opportunity, we expected the randomized job offer to shift people's employment trajectories. ${ }^{10}$

Instead, over the following year, the results painted a different picture: one where these young people used low-skill industrial jobs more as a safety net than a long-term job, and where self-employment and informal work were typically preferred to, and more profitable than, industrial jobs, at least when people had access to capital. More worryingly, this industrial safety net seems to have come with serious health risks.

First, looking at the cross-sectional and panel data, we see no evidence of an industrial wage premium in these firms. A simple nonexperimental wage comparison suggests that industrial jobs seemed to pay almost a quarter lower wages than informal opportunities.

Second, industrial work was associated with more stable employment hours, though only modestly. Whereas the sample had an average of 7.5 hours of work a week in the month before baseline, most were able to find full-time informal work by the time of the endline. Informal work also tended to pay higher wages than the industrial forms, but it typically came with the risk of short unemployment spells. Over the horizon of a month or a year, however, earnings in the industrial sector were no more stable than the alternatives.

Third, turnover in the industrial jobs was high, in part because higher-wage informal opportunities arose over time. A third of people offered a job quit the study firm in the first month, and 77 percent quit within the year. People generally quit the sector altogether, rather than simply switch firms. Firm managers said they found

\footnotetext{
increases girls' age at marriage and educational attainment.

${ }^{10}$ This push to formal employment, for instance, could not only reduce the uncertainty and volatility in their incomes and employment, but potentially improve their long-term employment and earnings potential through the experience and other human capital acquired in formal firms, or the potential to earn efficiency wages and other wage premiums.
} 
the high levels of turnover inconvenient, but were generally able to fill the positions with other low-skill workers.

Another reason people said they quit was that they found industrial work unpleasant and hazardous to their health. Those who quit described the jobs as difficult, poorly paid, and rigid. They also described a number of hazards, including chemical exposure.

Turning to the experimental impacts, our results suggest that, a year after job offers, the economic gains from industrial work were negligible and the health risks substantial. But the entrepreneurship program raised incomes by a third without significant health costs.

First, the main impact of the job offer is to increase someone's exposure to industrial work during the year: from three months in the control group to six months in the job group. But because of the high quit rates, the job offer only had a modest effect on long-term employment at the end of the year. At endline, only 32 percent of the job arm was employed in any factory or commercial farm, compared to 20 percent of the control group. Partly because of the high quit rates, but also because industrial jobs offered more hours at lower wages, we see no evidence that the job offer increased incomes on net.

Receiving the entrepreneurship program, however, deterred people from joining an industrial firm and raised their earnings. Those who received capital and training invested a large proportion of the grant and shifted from casual labor and industrial work to their own farms and petty business. Only 9 percent were in an industrial job at the end of the year, compared to 20 percent in the control group. Relieving constraints on self-employment reduced industrial labor supply. After a year, earnings in the entrepreneurship arm had risen by a third compared to the control group, without working significantly more hours. This was only a gain of $\$ 1$ a week, but an important gain since they only earned $\$ 3$ otherwise.

Turning to health impacts, industrial work appears to have doubled self-reported health problems. The number of people reporting "great difficulty" performing simple daily activities (such as lifting heavy items or walking a short distance) increased from 4 percent among controls to 7.3 percent in the industrial job offer arm. Qualitatively, workers reported repetitive stress, kidney, and respiratory issues. These health impacts are large and striking, especially considering that most respondents had quit the industrial job or the sector altogether by the end of the year. These impacts come from spending just three additional months that year in industry. For every additional month of industrial work induced by the job offer, people were 1.1 percentage points more likely to report a disability of some form.

Why did workers apply and take poorly paid, hazardous jobs? In qualitative interviews many of the applicants said they used industrial jobs as temporary employment to cope with adverse shocks and unemployment spells. Also, to some extent, as youth with little formal sector experience, they were uncertain about the nature of these jobs or their aptitude. They learned mainly through experience. Finally, we also see weak evidence that workers who have baseline characteristics associated with poor earning and employment aspects do see relative income gains from the job offer. Thus, workers with poor aptitude for informal work and self-employment might choose riskier work for higher compensation. This is clearly not the case for higher aptitude workers, however. 
Naturally, workers were probably not perfectly informed about job risks and quality of these jobs, and there is some evidence that they underestimated the risk. Nonetheless, our data suggest that workers understood the health risks, at least in part, did not update their assessment of the risks as a result of spending more time in industry, and that they were willing to bear these risks to cope with temporary unemployment spells. It is possible that the short-term earnings and ending of a temporary unemployment spell were the compensating differential for risk. The degree to which workers understand health risks and how they seek compensation is an important one for future research.

Otherwise, the search process for industrial work in Ethiopia seems to be relatively fast, with little hint of constraints on mobility or barriers to learning once in the positions. There is no indication that the opportunity cost of time in trying out one of these jobs is high for these disposable jobs. If not for the worrisome health effects of these jobs, this would look like a competitive, frictionless, integrated labor market.

\section{Setting}

Firms exporting from Asia are looking to Ethiopia as a new industrial hub (Economist 2014). The country has advantages from a manufacturer's point of view: low wages, a politically stable and foreign investment-friendly regime, a domestic market of 94 million people, and proximity to Europe. Yet the country also remains poor, as 78 percent live under $\$ 2$ a day in PPP terms, and agriculture employs 85 percent of the workforce.

Ethiopia has a long history of manufacturing, especially shoemaking, with some firms in existence since the 1930s. Until the 1990s, however, Ethiopia was a command economy with few private firms. In the last 20 years, the state has encouraged entry by private firms, with relatively limited controls. This has resulted in significant domestic investment in agribusiness and light manufacturing, as well as a significant foreign direct investment from Europe and Asia. In the years prior to our study, 2000-2008, national income and industrial output both grew about 10 percent per year, with the number of medium and large manufacturers doubling in number (CSA 2011). Ethiopia represents one of the continent's few committed attempts to attract labor-intensive industries.

The beginning of the study period was first a boom time followed by a mild slow down. Even so, during this period new foreign firms were entering the market and starting small plants, and some domestic firms were continuing to invest and expand. The period around our study, 2005-2015, saw rises in manufacturing value added between 8.6 and 16.9 percent per year in constant 2010 US dollars (World Bank 2015).11

Over the last two decades, there has also been a transformation in Ethiopia's urban labor markets. They have become more flexible, with rising importance of

\footnotetext{
${ }^{11}$ Manufacturing value added was substantially higher as a share of national income in the 1990s, after the end of the war and new market reforms, but this mainly reflects the low level of national income at the time rather than the size of the manufacturing base.
} 
private sector work, no obvious skill premiums between the private and public sector, and lower (but still considerable) urban unemployment. In all the firms in our study, and in general across the private sector, employers can set wages without any legal restriction or reference to union deals. The governing labor law makes it also relatively straightforward to fire an employee. Online Appendix VI elaborates.

\section{Experimental Design and Procedures}

We worked in five firms, described in Table 1, with details in online Appendix VII. The firms were from five sectors and four regions. Two firms hired more than one cohort over the study period, 2010-2013, for a total of eight cohorts. While this is a small number, the differences in timing, region, and sectors reduced the influence of idiosyncratic shocks. Three firms engaged in light manufacturing (textiles and garments, shoes, and beverages) and two in commercial agriculture (flowers and vegetables). With the exception of the import-competing beverage producer, all were export-oriented. Only one of the five was foreign-owned.

The positions required no experience, although the three manufacturers (not the two farms) required applicants to have completed grade 8 or 10. The jobs involved working on production lines-bottling water, picking and packing produce and flowers, cutting fabric, or sewing shoes. They could involve heavy machinery or simple tools.

The positions required people to work 45 to 50 hours per week over 5 or 6 days. At the time of the baseline surveys, the jobs typically paid a wage of $\$ 1$ to $\$ 1.50$ per day at 2010 market exchange rates (where $\$ 1=13.5$ birr in 2010). Some firms offered nonwage benefits such as on-site healthcare and bus transport.

The workplaces were professional and well-maintained, and firms never coerced employees. Nonetheless, health risks were common, especially: air quality (dust particles or chemical fumes); discomfort and fainting from standing or lack of breaks or water; and safety hazards such as wet floors, sharp instruments, and so forth. In interviews, workers who used cleaning solvents, pesticides, dyes, and glues sometimes reported fainting from inhalation.

Most firms were unionized, but these were generally worker associations that mediated disputes but did not engage in collective bargaining. Occasionally, however, we did observe short strikes or walkouts in response to salary delays.

\section{A. Site Selection}

We approached more than 300 private firms over two years, roughly half of all private industrial firms with 50 or more employees. ${ }^{12}$ We identified these firms through applications for investment certificates, public business listings, industry associations, and personal contacts. ${ }^{13}$ To be eligible for the study, a firm had to be

\footnotetext{
122009 census data suggest just over 500 private firms with more than 50 employees in the manufacturing sector and less than 100 export-oriented commercial farms (CSA 2011).

${ }^{13}$ These firms are not a representative sample of all firms, but rather were our attempt to contact all firms in textiles, leather, horticulture, and other manufacturing, especially firms that were expanding operations. We contacted most firms via phone or walk-in.
} 
TABle 1 - Characteristics OF OUR Study COHORTS AND InTERVEnTIONS

\begin{tabular}{|c|c|c|c|c|c|c|c|c|}
\hline \multirow[b]{2}{*}{ Characteristic } & \multicolumn{8}{|c|}{ Firm and cohort } \\
\hline & \multicolumn{2}{|c|}{$\begin{array}{l}\text { Beverage } \\
\text { producer }\end{array}$} & \multicolumn{2}{|c|}{$\begin{array}{c}\text { Flower } \\
\text { farm }\end{array}$} & $\begin{array}{l}\text { Shoe } \\
\text { factory }\end{array}$ & \multicolumn{3}{|c|}{$\begin{array}{l}\text { Garment and } \\
\text { textile factory }\end{array}$} \\
\hline Site type & \multicolumn{2}{|c|}{ Peri-urban } & Rural & Peri-urban & Urban & \multicolumn{3}{|c|}{ Peri-urban } \\
\hline Region & \multicolumn{2}{|c|}{ Oromia } & SNNP & Oromia & Addis & \multicolumn{3}{|c|}{ Tigray } \\
\hline Approximate number of employees & \multicolumn{2}{|c|}{150} & 250 & 2,000 & 1,400 & \multicolumn{3}{|c|}{700} \\
\hline Foreign owner? & \multicolumn{2}{|c|}{ No } & Yes & Yes & No & \multicolumn{3}{|c|}{ No } \\
\hline Exporter & \multicolumn{2}{|c|}{ No } & Yes & Yes & Yes & \multicolumn{3}{|c|}{ Yes } \\
\hline Unionized? & \multicolumn{2}{|c|}{ Yes } & No & Yes & Yes & \multicolumn{3}{|c|}{ Yes } \\
\hline Start date (MM/YY) & $04 / 10$ & $03 / 11$ & $10 / 11$ & $11 / 11$ & $01 / 13$ & $05 / 12$ & $05 / 13$ & $06 / 13$ \\
\hline Eligible sample & 53 & 68 & 89 & 152 & 158 & 89 & 140 & 188 \\
\hline Jobs available & 15 & 19 & 30 & 50 & 50 & 30 & 45 & 60 \\
\hline Monthly wage (current birr) & 350 & 350 & 574 & 535 & 734 & 417 & 420 & 420 \\
\hline Monthly wage (2010 birr) & 348 & 280 & 381 & 395 & 422 & 247 & 234 & 233 \\
\hline Weekly work hours & 48 & 48 & 48 & 47 & 44 & 48 & 48 & 48 \\
\hline \multicolumn{9}{|l|}{ Grants (after tax) } \\
\hline In current birr & & 4,872 & 5,016 & 4,969 & 5,773 & 5,124 & 5,849 & 5,884 \\
\hline In 2010 birr & & 3,594 & 3,330 & 3,293 & 3,278 & 3,048 & 3,266 & 3,196 \\
\hline In US dollars & & 290 & 290 & 290 & 315 & 290 & 315 & 315 \\
\hline Tranches & & 2 & 2 & 2 & 1 & 1 & 1 & 1 \\
\hline \multicolumn{9}{|l|}{ Applicants } \\
\hline Age & 22 & 24 & 23 & 22 & 24 & 22 & 21 & 20 \\
\hline Female & $64 \%$ & $44 \%$ & $77 \%$ & $100 \%$ & $66 \%$ & $52 \%$ & $100 \%$ & $100 \%$ \\
\hline Married & $15 \%$ & $22 \%$ & $31 \%$ & $34 \%$ & $34 \%$ & $10 \%$ & $25 \%$ & $8 \%$ \\
\hline Education & 11 & 11 & 6 & 6 & 12 & 10 & 11 & 9 \\
\hline
\end{tabular}

Notes: Firm data come from firm manager interviews. Applicant data come from a baseline survey, described in Section D.

in a manufacturing or commercial farm sector, expect to hire a batch of at least 15 low-skill, full-time workers, and be willing to randomly assign job offers within a pool of applicants the firm prescreened.

More than three-quarters of the firms we approached were open to the study. ${ }^{14}$ Few firms, however, had plans to open a new production line and hire a large batch of workers at once. One reason is that sector growth was slowing in this period. ${ }^{15}$ Also, some sector growth was coming from new firms, often foreign-owned, who were reluctant to participate because their start-up was already complicated enough. Most of all, few firms planned to hire their employees in bulk at one time, but rather planned to hire people piecemeal, to accommodate more gradual growth and cope with regular attrition.

Randomizing jobs proved uncontroversial in the labor-intensive industries that make up most of Ethiopian industry. While one might expect that firms want to select the best workers, low-skill entry-level positions were often filled without a

\footnotetext{
${ }^{14}$ They typically expressed interest in participation in the study for several reasons: curiosity in the answer, the opportunity to bring some structure to relatively unstructured hiring processes, and an interest in learning more about their applicant pool and the other opportunities available to their employees.

${ }^{15} 2010$ to 2012 in Ethiopia was a period of moderate government financial repression and preelection uncertainty. Despite a growing economy and a boom in some sectors, such as construction, many of the existing firms we approached were temporarily holding off on growth plans. Other common sources of delay included difficulty in obtaining licenses, foreign exchange, importing equipment, and obtaining parts. At least two other firms intended to participate, but suffered prolonged delays and did not open their new line during the study period.
} 
substantive interview process. In most of the firms we approached, human resource managers described entry-level hiring as ad hoc. For instance, we commonly witnessed firms filling low-skill positions on a first-come, first-hire manner, with little or no interview process.

What are these five study firms a case of? Our data suggest the jobs are similar to other labor-intensive, low-skill, entry-level positions in the large textile, garment, footwear, beverage, and commercial farming sectors, and thus different from positions in higher-skill and heavier or more capital-intensive manufacturing. Compared to a representative sample of industrial firms in 2014 in the capital Addis Ababa, our five firms had higher revenues, lower profits, two to three times as many production employees, and lower-skilled employees. ${ }^{16}$

It is reasonable to worry that firms willing to randomize employment were poorly managed or had unusual turnover. While possible, qualitatively we saw little difference between our firms and the others we approached. On the contrary, all were expanding employment, suggesting they had more credit and higher returns to investment than others.

\section{B. Stimulating Self-Employment through Grants and Training}

Starting with the second cohort, the entrepreneurship treatment arm offered people five days of business training and planning, followed by an unconditional cash grant of nearly 5,000 birr, or roughly $\$ 300$ at the time it was given (see Table 1)..$^{17}$ We chose the amount based on our qualitative assessment of the costs required to set up a part-time enterprise, plus the limits of what we could afford.

Professional skills trainers led classes of about 20, and each person also received individual mentoring during those 5 days. ${ }^{18}$ While we framed the cash grant as a business start-up fund, throughout the intervention we made clear that it was nonetheless an unconditional grant and grantees were free to use it as they saw fit—savings, consumption, or investment. Subjects had to complete at least three days of the training, however, to receive the grant.

\footnotetext{
${ }^{16}$ Given the low-skill nature of the work and the entry-level positions, starting salaries were lower than the manufacturing average - at roughly the twenty-fifth percentile of manufacturers in the capital. Since most of our firms are outside the capital, the purchasing power of their wages is greater, probably putting them between the twenty-fifth and fiftieth percentile in terms of wages. Moreover, comparing wages to the distribution quoted in the 2009/2010 census of manufacturing firms suggest that they were not at all uncommon for the specific sectors involved. The modal workers in the census earned between $400-600$ birr in 2010 prices, with the second most common interval 200-400 birr, jointly making up 40 percent of the workforce in manufacturing in general and more than 60 percent in textiles or footwear (CSA 2011). The wages of the workers in our sample fall in these ranges. See online Appendix III for data and analysis.

${ }^{17}$ Total implementation cost was roughly $\$ 450$ per person including the grant, training, and local program administration. The grant amount varied slightly from cohort to cohort because of inflation, currency devaluation, and tax issues. For cohorts 2 to 4, a for-profit firm ran the intervention and was required to withhold tax on the grants. To minimize the tax burden, the cash was disbursed in two tranches several weeks apart. We used a for-profit firm because we could not find a nonprofit organization willing to disburse cash without conditions at low cost. For cohorts 5 to 8 , we ran the intervention through a parastatal research organization to avoid the tax burden. The amount of the grant was increased to maintain the rough purchasing power and disbursed in a single tranche to reduce implementation costs.

${ }^{18}$ Cohorts 2 and 3 also received a follow-up visit by the trainer after three months for additional advice. Grantees did not see this service as helpful, and given the cost it was discontinued after cohort 3.
} 


\section{Experimental Procedures}

We generally followed each firm's standard procedures for hiring batches of new employees to staff new production lines: the firms advertised jobs through a posting on the front gate, word of mouth, and local job boards. ${ }^{19}$

Applicants were instructed to gather on a specific day. Firm managers would then screen written or verbal applications, typically based on firm- or job-specific minimum education and health requirements. Some firms also preferred specific age ranges or genders for different positions. Across the study cohorts, between 75 and 95 percent of applicants passed these criteria and thus entered the study sample. We do not have data on ineligible applicants.

A research team from Innovations for Poverty Action (IPA) and the Ethiopian Development Research Institute (EDRI) then debriefed eligible applicants on the random assignment to the job, and informed them for the first time about the entrepreneurship program. Thus, all were aware of the possibility of a grant. Nearly all agreed to enter the study and were invited to complete a baseline survey and enter the lottery, stratified by gender. 304 were assigned to receive a job offer, 285 to receive the entrepreneurship program, and 358 to a control group. The firm posted the names of people receiving the job offer at the factory site and a member of the IPA/EDRI research team contacted all those assigned to the job or entrepreneurship program. Job offers began within a few days. We gave each firm a list of unsuccessful applicants and asked the firm not to hire them for at least 12 months. In practice, however, the firms kept poor records and within a few days or weeks of the randomization could have hired control group members.

\section{Study Participants and Balance}

Table 2 reports characteristics of the eligible applicants at baseline from self-reported surveys and tests of balance. ${ }^{20}$ Eighty percent were women. The average applicant was 22 and had completed grade 9. Most were unmarried. They had 7.5 hours of work per week, typically a portfolio of activities such as farming, casual labor, or petty business. They had earned little cash in the previous month. Only 27 percent had worked in a large, formal firm before, and only 19 percent in a factory. Based on qualitative interviews, most applicants had only a hazy idea of the type and difficulty of the work in advance, and often only learned the salary being offered at the time of hiring.

\footnotetext{
${ }^{19}$ In order to ensure sufficient applicants, we only made one change to standard procedures: we assisted the firm in posting more notices within a wider radius than usual (usually no more than a few kilometers). Since the firm typically drew employees from this radius, we expected this to generate an applicant pool very similar to the usual one. It is possible, however, that the experimental pool of applicants is further outside the family/friend network, and lives slightly further from the factory than would otherwise have been the case. That said, most applicants live within a few miles of the firm, and so are extremely local by any measure. (The firms, who were reluctant to hire people who lived far away, reported that they did not think the distance would make a material difference, since all live nearby.)

${ }^{20}$ Applicants completed a 90-minute baseline survey plus 45 minutes of interactive games, with real money, to measure time and risk preferences, and cognitive abilities such as executive function. An Ethiopian enumerator delivered surveys and the games verbally in the local language. The games remunerated the respondent with roughly a half days' wages.
} 
Table 2-Baseline Summary Means and Test of Randomization Balance

\begin{tabular}{|c|c|c|c|c|c|}
\hline \multirow{3}{*}{ Baseline covariate $(n=947)$} & \multirow{3}{*}{$\begin{array}{c}\text { Control } \\
\text { mean } \\
(n=358) \\
(1)\end{array}$} & \multicolumn{4}{|c|}{ Balance test (OLS) } \\
\hline & & \multicolumn{2}{|c|}{ Job-Control } & \multicolumn{2}{|c|}{ Entrepreneur-Control } \\
\hline & & $\begin{array}{c}\text { Diff. } \\
(2)\end{array}$ & $\begin{array}{c}p \text {-value } \\
\text { (3) }\end{array}$ & $\begin{array}{c}\text { Diff. } \\
(4)\end{array}$ & $\begin{array}{c}p \text {-value } \\
(5)\end{array}$ \\
\hline Female & 0.80 & & & & \\
\hline Age & 22.02 & -0.12 & 0.68 & -0.14 & 0.63 \\
\hline Unmarried & 0.81 & -0.06 & 0.07 & -0.04 & 0.25 \\
\hline Muslim & 0.05 & -0.00 & 0.90 & 0.00 & 0.98 \\
\hline Household size & 4.35 & -0.13 & 0.45 & -0.14 & 0.45 \\
\hline Household head & 0.23 & 0.04 & 0.25 & -0.00 & 0.96 \\
\hline Proportion household dependents & 0.43 & -0.00 & 0.98 & -0.00 & 0.96 \\
\hline Total years of education and training & 9.31 & -0.20 & 0.34 & -0.02 & 0.92 \\
\hline Executive function, $z$-score & 0.11 & -0.18 & 0.01 & -0.13 & 0.08 \\
\hline Weekly cash earnings (2010 birr) & 9.57 & 0.59 & 0.81 & -1.44 & 0.57 \\
\hline Durable assets, $z$-score & 0.09 & -0.11 & 0.13 & -0.13 & 0.06 \\
\hline Ever worked in a large firm & 0.27 & -0.03 & 0.43 & 0.05 & 0.18 \\
\hline Average weekly hours of work & 7.52 & -0.09 & 0.94 & -0.36 & 0.80 \\
\hline No work in past 4 weeks & 0.68 & 0.01 & 0.86 & -0.01 & 0.76 \\
\hline Highest-lowest earnings, past month & 181.38 & 39.44 & 0.05 & 15.84 & 0.33 \\
\hline Could borrow 3,000 birr & 0.31 & 0.04 & 0.27 & -0.00 & 0.98 \\
\hline Ability to do activities of daily life (0-15) & 14.32 & 0.09 & 0.40 & 0.10 & 0.31 \\
\hline Disability (great difficulty at $>1$ ADL) & 0.01 & -0.01 & 0.26 & -0.00 & 0.77 \\
\hline Risk aversion, $z$-score & -0.01 & -0.05 & 0.55 & 0.10 & 0.20 \\
\hline Future orientation, $z$-score & 0.10 & -0.06 & 0.45 & -0.03 & 0.73 \\
\hline Locus of control index, $z$-score & -0.04 & 0.04 & 0.62 & 0.13 & 0.12 \\
\hline Self-esteem index, $z$-score & -0.05 & 0.03 & 0.75 & 0.06 & 0.42 \\
\hline Family relations index, $z$-score & -0.05 & -0.02 & 0.77 & 0.07 & 0.35 \\
\hline Friends and neighbors relations index & -0.01 & -0.05 & 0.49 & 0.00 & 0.95 \\
\hline Change in subjective well-being, past yr. & 0.22 & 0.20 & 0.03 & 0.09 & 0.33 \\
\hline Symptoms of depression, $z$-score & -0.02 & 0.02 & 0.82 & 0.01 & 0.94 \\
\hline Symptoms of anxiety, $z$-score & -0.04 & 0.05 & 0.50 & -0.01 & 0.92 \\
\hline Aggressive or hostile behaviors, $z$-score & 0.04 & -0.06 & 0.44 & -0.13 & 0.11 \\
\hline Conscientiousness index, $z$-score & -0.00 & 0.01 & 0.89 & 0.04 & 0.65 \\
\hline Years experience, private firm & 0.34 & 0.17 & 0.08 & 0.22 & 0.02 \\
\hline Years experience, workshop & 0.01 & 0.00 & 0.73 & 0.01 & 0.27 \\
\hline Years experience, government/NGO & 0.08 & -0.02 & 0.67 & 0.02 & 0.73 \\
\hline Probability of better job, next month & 0.68 & -0.01 & 0.47 & -0.01 & 0.72 \\
\hline Probability of full-time work, next month & 0.55 & 0.01 & 0.74 & 0.03 & 0.17 \\
\hline \multicolumn{2}{|l|}{$p$-value from $F$-test of joint significance } & \multicolumn{2}{|c|}{0.04} & \multicolumn{2}{|c|}{0.01} \\
\hline Observations & & \multicolumn{2}{|c|}{662} & \multicolumn{2}{|c|}{643} \\
\hline
\end{tabular}

Notes: Medians are imputed for baseline variables with missing observations. Treatment and control group differences are calculated using an OLS regression of each covariate on treatment indicators plus block (cohort-gender) fixed effects. Balance tests for the female dummy are omitted because randomization was blocked on gender. Standard errors are heteroskedastic-robust.

The experimental sample was imbalanced across the treatment arms at baseline. As Table 2 shows, of the 34 covariates across two treatments, 8 of the 68 mean differences $(12$ percent $)$ have $p<0.1$. Those assigned to jobs are less likely to be married and have slightly lower executive functions and education compared to the control group. Those assigned to the entrepreneurship program have lower assets and more firm experience. A test of joint significance of all covariates has a $p$-value of 0.04 for the job offer and 0.01 for the entrepreneurship program. To minimize bias, we control for baseline covariates when estimating treatment effects. 


\section{E. Outcomes and Attrition after One Year}

We ran endline surveys 11 and 13 months after job offers, for two rounds of data on low-autocorrelation outcomes (such as weekly employment hours and earnings), thus increasing statistical precision in a fixed sample (McKenzie 2012). ${ }^{21}$ At 11 months, we also attempted to interview the household head for household labor allocations, wealth, and attitudes. Our sample frequently moved between survey rounds. As online Appendix Table IV.6 reports, we tracked 88 percent of individuals after 11 months, 85 percent after 13 months, and also interviewed 90 percent of their households.

Online Appendix Table IV.12 shows that 5.3 percent were not interviewed because they traveled to the Middle East for temporary domestic work and construction. Based on qualitative interviews with emigrants, these jobs can pay significantly higher wages than domestic factories, but may have fixed costs of entry and potentially severe disamenities, such as extremely long hours, no days off, infrequent family contact, restricted freedoms, and sometimes abuse. We know whether someone emigrated, but we do not have survey outcomes. Based on household interviews, we estimate 4 percent of the control group emigrated, and emigration is 2.1 percentage points higher among those assigned to a job and 2.8 points higher among those assigned to a grant (both effects have a standard error of 0.017 and so are not statistically significant). Since there is a small treatment differential, this could mean that the estimated income treatment effects are too low, and estimated impacts on quality of life measures (such as mental health) are too low. We bound treatment effects for different attrition scenarios in Section F, and see no reason migration should affect our core conclusions.

Overall, across the two surveys, response rates were 87.4 percent in the job arm, 87.4 percent in the entrepreneurship arm, and 84.2 percent in the control arm. When controlling for baseline covariates, attrition (including emigration) is 2.3 percentage points higher in the control group than the treatments, but this is not statistically significant. ${ }^{22}$ Attrition is, however, associated with covariates: it is higher among women and those who were poorer, had less formal sector experience, and were less conscientious at baseline. ${ }^{23}$ This is a further reason to control for baseline covariates when calculating treatment effects.

\section{F. Qualitative Data}

During site visits to several dozen factories and commercial farms, we conducted informal interviews with workers and managers. At each study firm, we systematically interviewed managers at every level from senior management to line managers. Research assistants also interviewed 138 workers and microenterprise owners,

\footnotetext{
${ }^{21}$ See online Appendix IV.F for a comparison of results from just one round of data collection versus two, to demonstrate the value added of adding the second round. The point estimates are slightly higher with just one round of data, but the precision is much lower.

${ }^{22}$ Online Appendix IV.A reports response rates by round and treatment, and the correlates of attrition.

${ }^{23}$ The $p$-value on a joint test of significance of baseline covariates is $<0.001$. Conscientiousness is a personality trait that indicates lower perseverance and discipline.
} 
TABle 3-TAKe-Up of Treatments And Turnover

\begin{tabular}{|c|c|c|c|c|c|c|c|c|}
\hline \multirow[b]{3}{*}{ Dependent variable } & \multirow{2}{*}{\multicolumn{4}{|c|}{$\begin{array}{l}\text { Proportion who take up by } \\
\text { treatment assignment }\end{array}$}} & \multicolumn{4}{|c|}{ Take-up differences (OLS) } \\
\hline & & & & & \multicolumn{2}{|c|}{$\begin{array}{l}\text { Job- } \\
\text { Control }\end{array}$} & \multicolumn{2}{|c|}{$\begin{array}{l}\text { Entrepreneur- } \\
\text { Control }\end{array}$} \\
\hline & $\begin{array}{l}\text { Job } \\
(1)\end{array}$ & $\begin{array}{c}\text { Entrepreneur } \\
(2)\end{array}$ & $\begin{array}{c}\text { Control } \\
(3)\end{array}$ & $\begin{array}{l}\text { Obs. } \\
(4)\end{array}$ & $\begin{array}{c}\text { Coeff. } \\
(5)\end{array}$ & $\begin{array}{l}\text { SE } \\
(6)\end{array}$ & $\begin{array}{l}\text { Coeff. } \\
(7)\end{array}$ & $\begin{array}{l}\text { SE } \\
(8)\end{array}$ \\
\hline \multicolumn{9}{|l|}{ Employment in a study firm: } \\
\hline Was directly informed of a job offer ${ }^{\dagger}$ & 0.99 & 0.00 & 0.04 & 947 & 0.964 & {$[0.020]$} & -0.027 & [0.017] \\
\hline Worked at least a day ${ }^{\dagger}$ & 0.89 & 0.07 & 0.14 & 947 & 0.753 & {$[0.039]$} & -0.081 & {$[0.041]$} \\
\hline Worked at least a month ${ }^{\dagger}$ & 0.69 & 0.07 & 0.13 & 947 & 0.569 & {$[0.044]$} & -0.071 & {$[0.032]$} \\
\hline Was working in study firm at endline & 0.21 & 0.01 & 0.03 & 1,841 & 0.172 & {$[0.017]$} & -0.016 & {$[0.012]$} \\
\hline \multicolumn{9}{|l|}{ Employment in formal or industrial sectors: } \\
\hline Worked at least a month in formal sector & 0.91 & 0.53 & 0.69 & 1,628 & 0.225 & {$[0.032]$} & -0.158 & [0.041] \\
\hline Worked at least a month in any industrial firm & 0.83 & 0.26 & 0.43 & 835 & 0.408 & {$[0.057]$} & -0.153 & {$[0.020]$} \\
\hline Number of months worked in any industrial firm & 5.98 & 1.43 & 3.16 & 835 & 2.943 & {$[0.387]$} & -1.496 & {$[0.267]$} \\
\hline Was working in any industrial firm at endline & 0.32 & 0.09 & 0.20 & 1,587 & 0.107 & {$[0.023]$} & -0.118 & [0.016 \\
\hline \multicolumn{9}{|l|}{ Entrepreneur and training intervention: } \\
\hline Offered grant and training $^{\dagger}$ & 0.00 & 0.97 & 0.00 & 947 & & & 0.970 & {$[0.019]$} \\
\hline Received grant and training ${ }^{\dagger}$ & 0.00 & 0.94 & 0.00 & 947 & & & 0.938 & {$[0.029]$} \\
\hline
\end{tabular}

Notes: A study firm is one of our five firms. The formal sector includes any formal firm with ten or more employees in any sector. By "industrial firm" we mean any manufacturer or commercial farm. Indicators for working at least a month in a firm since baseline are equal to 1 if it was reported in the 11- or 13-month endline. The number of months worked in a firm since baseline is calculated up to the 13-month endline, where those data are available. The indicator for working in any firm at endline equals one if they reported such work at either endline. The estimates in columns 5 to 8 come from OLS regressions of the dependent variable on assignment to job and assignment to entrepreneurship program with cohort dummies and the baseline control vector listed in Table 2.

${ }^{\dagger}$ Data drawn from project administrative data rather than the endline survey data. Directly informed of a job offer means one of the study staff reached them in phone or person.

both in and out of the sample. They also conducted 60 exit interviews by phone with sample members who quit the study firms.

\section{Descriptive Analysis}

Some of the first insights into industrial work come from collecting and analyzing panel data on largely unemployed industrial job seekers. In addition to reporting take-up of the experimental treatments, this section discusses what summary statistics and observational analysis tell us about the treatment arms and employment opportunities in their absence.

\section{A. Job Take-Up, Retention, and Turnover}

First, we see that large numbers of people applying for industrial jobs turned down a job offer or quit quickly. Within a few months of the offer, most quit the job and the industrial sector as a whole. Table 3 reports the take-up and turnover rates treatment arm.

If offered the job, 10 percent did not show up the first day. A further 20 percent quit within a month. After a year, 77 percent had quit the study firm (there were very few firings or involuntary separations). Meanwhile, 13 percent of the control group was hired by a study firm during the year. Most of these people quit as well. Controlling for covariates, assignment to a job increased the chances an applicant 
held that job for at least a month by 57 percentage points relative to the control group, but assignment to a job offer increased the probability they held that job at endline by just 17 percentage points.

People did not simply quit the factory job: they tended to leave the sector altogether. Between baseline and endline, 69 percent of the control group held a formal sector job of any form for a least a month, and 43 percent worked in some kind of industrial firm. Being assigned a job offer to one of our study firms increases the probability of working a month or more in an industrial firm by 41 percentage points. Being assigned to the entrepreneurship program, meanwhile, decreases this probability by 15 percentage points. ${ }^{24}$

After a year, only 32 percent of those assigned to an industrial job still worked in the sector in the month before the survey, versus 20 percent in the control group. In exit interviews, many reported that they quit despite having no outside opportunity at that time.

Thus, the real treatment here is the amount of time working in the industrial sector. The control group worked 3.16 months in the sector, compared to 5.98 months in the treatment group and 1.43 months in the grants group. As a consequence, below we will examine both intent-to-treat effects as well as complier average causal effects using assignment to treatment as an instrument for length of time in the industrial sector.

Who stayed versus who quit? Table 4 reports the correlates of industrial job retention among those assigned to the industrial job offer or the control group (results are similar regardless of the sample we use). Those who stayed were older and had less formal work experience, lower executive function, ${ }^{25}$ lower conscientiousness, greater physical health (measured by a self-reported disability, discussed below), and weakly greater future orientation (based on self-reported time preferences plus play in incentivized games). ${ }^{26}$ One interpretation is that people with observable human capital (education, experience) had good outside options, while those with less observable skills and productivity (future orientation, or productivity reflected in their initial outside earnings) were less likely to leave.

\section{B. Grant Use}

We do not have precise investment figures, but we returned to all grant recipients 6-8 weeks after the grant and asked them to describe how they had used the cash by allocating 30 tokens across 12 pictures representing different expenditures. They indicated that 55 percent of the grant went to business materials or investments, 35 percent to savings or cash on hand, and 10 percent to consumption or transfers. Money is fungible (among other weaknesses of these data), but nonetheless, the

\footnotetext{
${ }^{24}$ Of those assigned to the entrepreneurship program, 3 percent could not be reached and 2 percent declined the training and cash or dropped out midway, typically (they said) due to illness or a preference for full-time work.

${ }^{25}$ Also known as working memory, it is used to perform activities such as planning, organizing, strategizing, paying attention to details, and managing time and space. We measure it through a combination of forward and backward digit recall tests, as well as a modified Stroop test that tests inhibitory control.

${ }^{26}$ We have survey questions related to patience and self-control in everyday situations. We also play games involving trade-offs of real money over time, which we use to calculate a discount rate. We average all measures and standardize the index.
} 
Table 4-Baseline Correlates of Industrial Job Retention, Job and Control Arms Only $(N=518)$

\begin{tabular}{|c|c|c|c|c|}
\hline \multirow[b]{2}{*}{ Baseline covariate } & \multicolumn{2}{|c|}{$\begin{array}{l}\text { Number of months worked in } \\
\text { any industrial firm } \\
\text { since baseline }\end{array}$} & \multicolumn{2}{|c|}{$\begin{array}{l}\text { Working in any industrial } \\
\text { firm at endline }\end{array}$} \\
\hline & $\begin{array}{l}\text { Coefficient } \\
\text { (1) }\end{array}$ & $\begin{array}{c}\text { Standard error } \\
\text { (2) }\end{array}$ & $\begin{array}{c}\text { Coefficient } \\
\text { (3) }\end{array}$ & $\begin{array}{c}\text { Standard error } \\
\text { (4) }\end{array}$ \\
\hline Age & 0.167 & {$[0.096]$} & 0.017 & {$[0.008]$} \\
\hline Female & -0.039 & {$[0.924]$} & 0.101 & {$[0.084]$} \\
\hline Unmarried & -0.032 & {$[0.719]$} & 0.013 & {$[0.066]$} \\
\hline Household head & -0.611 & {$[0.705]$} & -0.065 & {$[0.063]$} \\
\hline Disability indicator & -3.749 & {$[1.706]$} & -0.431 & {$[0.134]$} \\
\hline Total years of education and training & -0.129 & {$[0.109]$} & -0.003 & {$[0.010]$} \\
\hline Cognitive ability, $z$-score & -0.621 & {$[0.288]$} & -0.074 & {$[0.028]$} \\
\hline Mental health, $z$-score & -0.420 & {$[0.291]$} & -0.029 & {$[0.027]$} \\
\hline Conscientiousness index, $z$-score & -0.359 & {$[0.343]$} & -0.060 & {$[0.032]$} \\
\hline Risk aversion, $z$-score & -0.189 & {$[0.285]$} & -0.036 & {$[0.028]$} \\
\hline Future orientation, $z$-score & 0.409 & {$[0.294]$} & 0.048 & {$[0.026]$} \\
\hline Income and wealth, $z$-score & -0.110 & {$[0.342]$} & 0.005 & {$[0.032]$} \\
\hline Years experience in formal work & -0.559 & {$[0.233]$} & -0.044 & {$[0.024]$} \\
\hline Ever worked in industrial firm & 0.801 & {$[0.832]$} & 0.010 & {$[0.084]$} \\
\hline Prospects for employment in next month $(0-1)$ & 0.004 & {$[1.263]$} & 0.027 & {$[0.118]$} \\
\hline Mean of dependent variable & \multicolumn{2}{|c|}{5.038} & \multicolumn{2}{|c|}{0.320} \\
\hline$R^{2}$ (including fixed effects) & \multicolumn{2}{|c|}{0.106} & \multicolumn{2}{|c|}{0.129} \\
\hline$F$-test of joint significance ( $p$-value $)$ & \multicolumn{2}{|c|}{0.029} & \multicolumn{2}{|c|}{0.001} \\
\hline
\end{tabular}

Notes: All regressions use OLS pooling, 11- and 13-month surveys, and include cohort-gender fixed effects. Standard errors are robust and clustered by participant.

exercise implies that the young people sought to smooth the income shock and put at least $\$ 165$ of the $\$ 300$ into enterprises.

\section{Employment and Earnings in and out of Industrial Work}

At baseline, most applicants had little work or earnings. So why quit a permanent job? First, the panel data suggest that applicants were in a temporary employment slump, perhaps because they had recently lost a job, were new entrants, or were reentering the labor market after a period of no employment. Hence, baseline earnings and employment levels did not reflect most people's options over a longer horizon.

In the control group, the share of participants with no employment hours fell from 68 percent at baseline to 36 percent at endline, and average hours of work per week rose from 7.5 to $26 .{ }^{27}$ As a result, average weekly earnings in the control group more than tripled from baseline to endline, from 9 to 33 birr (all values in 2010 prices). Most of their work was in the informal sector: farm or casual labor, petty business, or salaried work in an informal firm. This is unlikely to come from a common labor demand shock. The eight cohorts of hires began at different points in time and space over two years, with varied macroeconomic conditions.

Second, while receiving an industrial job increased the hours and earnings available, and reduced the risk of an unemployment spell, industrial work paid wages

\footnotetext{
${ }^{27}$ The largest increases in hours came from factory and farm wage labor, casual nonfarm labor (e.g., construction), and salaried labor in nonindustrial organizations (such as shops, offices, etc.).
} 
Table 5-Industrial Employment, Earnings, and Wage Premiums at Endline

\begin{tabular}{|c|c|c|c|c|}
\hline & \multicolumn{4}{|c|}{ Dependent variable } \\
\hline & $\begin{array}{c}\text { Unemployed } \\
(<5 \text { hours work } \\
\text { per week }) \\
(1)\end{array}$ & $\begin{array}{l}\text { Weekly } \\
\text { work } \\
\text { hours } \\
(2)\end{array}$ & $\begin{array}{l}\text { Weekly cash } \\
\text { earnings } \\
\text { (birr) } \\
\text { (3) }\end{array}$ & $\begin{array}{l}\text { Earnings } \\
\text { per hour } \\
\text { (birr) } \\
\text { (4) }\end{array}$ \\
\hline $\begin{array}{l}\text { Mean, people with no industrial work } \\
\text { (including unemployed) }\end{array}$ & 0.50 & 20.66 & 27.92 & 1.59 \\
\hline $\begin{array}{l}\text { Mean increase among people with any } \\
\text { industrial work (with baseline covariates) }\end{array}$ & $\begin{array}{r}-0.47 \\
{[0.026]}\end{array}$ & $\begin{array}{l}23.45 \\
{[1.468]}\end{array}$ & $\begin{array}{l}26.04 \\
{[5.408]}\end{array}$ & $\begin{array}{l}-0.38 \\
{[0.175]}\end{array}$ \\
\hline $\begin{array}{l}\text { Mean increase among people with any industrial } \\
\text { work (without baseline covariates) }\end{array}$ & $\begin{array}{l}-0.48 \\
{[0.025]}\end{array}$ & $\begin{array}{l}23.88 \\
{[1.421]}\end{array}$ & $\begin{array}{l}27.08 \\
{[5.446]}\end{array}$ & $\begin{array}{l}-0.39 \\
{[0.177]}\end{array}$ \\
\hline Observations & 1,087 & 1,087 & 1,088 & 681 \\
\hline $\begin{array}{l}\text { Mean, people with no industrial work } \\
\text { (excluding unemployed) }\end{array}$ & & 41.50 & 54.71 & 1.45 \\
\hline $\begin{array}{l}\text { Mean increase among people with any industrial } \\
\text { work (with baseline covariates) }\end{array}$ & & $\begin{array}{l}4.44 \\
{[1.492]}\end{array}$ & $\begin{array}{l}2.67 \\
{[6.731]}\end{array}$ & $\begin{array}{l}-0.24 \\
{[0.165]}\end{array}$ \\
\hline $\begin{array}{l}\text { Mean increase among people with any } \\
\text { industrial work (without baseline covariates) }\end{array}$ & & $\begin{array}{l}4.17 \\
{[1.492]}\end{array}$ & $\begin{array}{l}2.70 \\
{[6.685]}\end{array}$ & $\begin{array}{l}-0.25 \\
{[0.165]}\end{array}$ \\
\hline Observations & & 671 & 671 & 671 \\
\hline
\end{tabular}

Notes: Survey responses at 11 and 13 months are pooled. Industrial work is an indicator for positive hours in factory work any time in the 2 weeks prior to the 11- or 13-month survey. "Unemployed" means less than 5 hours of work per week, on average, across the weeks of work reported in the 11- and 13-month surveys. The "Mean increase among people with any industrial work" is the coefficient on an indicator industrial work in an OLS regression of each dependent variable on an indicator for having any factory or commercial farm work at endline, plus baseline covariates and cohort fixed effects. Earnings per hour are undefined if there were zero work hours reported. Standard errors are robust and clustered by individual.

that were similar or lower than most people's nonindustrial options. Table 5 reports employment and earnings for those with and without any industrial work at endline. Our estimate of the premium from industrial work comes from an OLS regression of each outcome on an indicator for any employment in a factory or farm at endline plus select baseline covariates and cohort fixed effects. ${ }^{28}$ We look at this premium with and without the "unemployed" (which for the purposes of this table we redefine as those with fewer than five hours of work per week). We can also look with and without baseline controls to observe selection effects.

At endline, 39 percent of the sample worked fewer than 5 hours per week. Including these "unemployed" (in the top panel of Table 5), people outside factory work had only about 20.7 hours of work a week and 28.0 birr in weekly earnings. Conditional on having 5 or more hours of work a week (bottom panel), the nonindustrial opportunities were better: 41.5 hours a week, and 54.7 birr in earnings.

\footnotetext{
${ }^{28}$ To the extent that these covariates capture the endogenous determinants of occupational choice and matching with an industrial firm, the coefficient on the factory/farm work indicator can be interpreted as the causal effect of industrial jobs. This assumption of conditional unconfoundedness is probably too strong, and the coefficient is undoubtedly biased, but it nonetheless gives, to a first approximation, a sense of the returns to industrial work. We cannot use assignment to an industrial job as an instrument since it would violate the exclusion restriction; assignment to a factory job could affect current earnings even if a year later the individual is no longer in the job.
} 
Overall, the data suggest that an industrial job increased hours and the potential for total earnings because (if people stayed in the job) it limited unemployment spells that came with the unpredictable and often temporary nature of mostly informal work. Compared to people employed in other sectors, there was an increase in hours and total earnings from working in an industrial firm, but only the rise in hours is statistically significant.

More striking, the coefficient on earnings per hour in an industrial job is actually negative and statistically significant at the 5 percent level. It appears that, if anything, industrial work is more poorly remunerated than nonindustrial work (when such work is available).

\section{Experimental Analysis}

To estimate program impacts on outcome $Y$, we calculate the intent-to-treat (ITT) estimate of an offer of a job or entrepreneurship program via OLS:

$$
Y_{i r j}=\alpha_{j}+\gamma_{r=13}+\theta_{J} J_{o b} b_{i j}+\theta_{E} \text { Entrepreneur }_{i j}+\beta X_{i j}+\varepsilon_{i j},
$$

where Job and Entrepreneur are indicators for random assignment to the treatment arms. We control for the baseline covariates, $X$, listed in Table 2, as well as gender-cohort fixed effects, $\alpha_{j}$. We pool both 11- and 13-month survey rounds, $r$, and we include a fixed effect for the 13-month round and cluster (robust) standard errors by individual. In principle, the request not to hire the control group members for a short while is a violation of the stable unit treatment values assumption (SUTVA) but given that this request was short term and (as we will see) mainly ignored, it is unlikely to affect our estimates of impact.

Our tables also report $\theta_{J}-\theta_{E}$, but except for the artificial environment of this research project, the grant is not a meaningful counterfactual for the job offer, and so the difference should be taken with caution. It is useful for comparing whether the risks or benefits of industrial work are echoed in entrepreneurial work.

Note that all outcomes are self-reported, and each treatment arm was aware of their assignment and the existence of other arms. Thus, there is the potential for self-reported outcomes to vary with treatment status. As with most low-income countries, there are no administrative data on earnings. And as with most countries, there are no systematic and available administrative data on health or informal earnings.

Complier Average Causal Effects.-Finally, given the high quit rates, we also calculate a complier average treatment effect (CATE), where we use Job as an instrument for the number of months since baseline the person worked in a formal firm with ten or more employees. The CATE approximates the effect of staying longer in industrial work. Those in the control group worked an average of 3.2 months in a formal job, and this roughly doubles with a job offer. ${ }^{29}$

\footnotetext{
${ }^{29}$ There are reasons to treat this CATE with caution. In principle, a job offer could affect outcomes through some mechanism other than weeks worked (e.g., people who learn and quit after a day). Also, using the number of
} 
Transitory versus Permanent Impacts.- To the extent that study subjects are in a temporary unemployment spell at baseline, the job offer will lead to an immediate increase in employment and income relative to control group subjects, who remain in an unemployment spell. We did not measure these short term, largely mechanical increases in income and employment. Rather, we measure income and employment 11 and 13 months later. We anticipated that any transitory shocks leading subjects to apply to the factory at baseline would be resolved by this time. As a result, our research design was intended to capture the more permanent effects on income, employment, and other aspects of well-being. That said, if unemployment spells tend to be long in the absence of the job offer, there is a risk that any treatment effect on income or employment reflects the persistence of transitory shocks. This is especially true for permanent income measures, such as consumption or assets.

Multiple Comparisons. - This experiment predated the development of the social science registry, but we documented our theoretical priors in a short policy note discussing "pilot results" from the very first hiring cohort. ${ }^{30}$ To reduce the number of hypothesis tests, we follow Kling, Liebman, and Katz (2007) and collect major outcomes into family indexes - additive, standardized indexes of related outcomes. Four are directly affected by industrial work: employment, income, physical health, and mental health. Four are indirect, in that changes are likely to be a result of "first-stage" changes in one of the direct outcomes: attitudes to industrial work/ firms, social integration, autonomy, and noncognitive skills. ${ }^{31}$ Finally, the paper reports treatment effects on all outcomes measured in the survey. We collected a small number of measures on time use, school enrollment, emigration, or workplace conditions for largely descriptive or exploratory purposes, and these do not easily fit into the eight major families above. We discuss impacts on these other outcomes in the text, but report treatment effects in the online Appendix.

In addition to variable reduction, we also consider more conservative $p$-values to account for the fact that we are testing multiple hypotheses. Below we present unadjusted standard errors as well as $p$-values adjusted for multiple comparisons, so that readers can use the threshold appropriate to their question and preferences. We use the Westfall and Young (1993) free step-down resampling method for the family-wise error rate (FWER), the probability that at least one of the true null hypotheses will be falsely rejected, using randomization inference. ${ }^{32}$ All results are

months in industrial work as the endogenous variable assumes a linear effect size, but if the effect is not linear, then the random job offer will not necessarily be a valid instrument (since it will also affect number of weeks squared and other nonlinear terms). As an approximation, however, these CATE results give us a sense of the consequences of longer time in industrial work. Alternatively, we could use "had any industrial work" as the endogenous variable. Since almost 90 percent work at least a day when offered a job, however, the results would not be materially different than a simple ITT, and any other indicator (such as "worked at least a month in an industrial job") would not pass the exclusion restriction.

${ }^{30} \mathrm{http} / / / \mathrm{www}$.theigc.org/publication/more-sweatshops-for-africa-pilot-results-from-an-experimental-study-ofindustrial-labor-in-ethiopia-policy-brief/.

${ }^{31}$ The direct outcomes, plus social integration, were the focus of the published policy note, prior to endline data collection on seven of the eight cohorts, illustrating that this division and emphasis is not simply post hoc.

${ }^{32}$ Other papers taking this approach include Kling, Liebman, and Katz (2007); Casey, Glennerster, and Miguel (2012); and Anderson (2008). Using the Westfall-Young bootstrap and the Holm-adjusted Bonferroni methods yields similar results. 


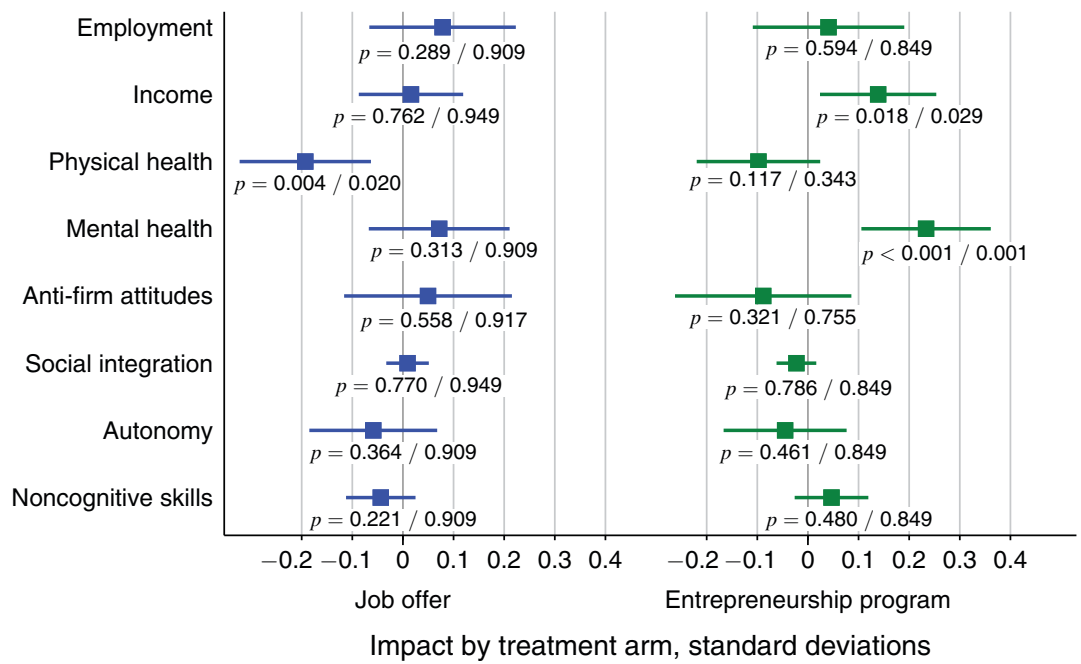

Figure 1. Program Impacts on Standardized Family Indexes, with 95 Percent Confidence Intervals and UNADJUSTED/ADJUSTED $p$-VALUES

Notes: The figure reports the effect of each treatment arm, averaging the 11- and 13-month survey outcomes. It also reports the difference between the two treatment arms. Treatment effects are estimated via OLS controlling for baseline covariates and block fixed effects. Each summary index is the standardized mean of composite outcomes. Standard errors are heteroskedastic-robust.

robust to fairly conservative adjustments, such as for all eight family indexes (direct and indirect). Figure 1 summarizes the one-year ITT estimates of the effect of each treatment on standardized indexes for the eight direct and indirect outcome families, including both unadjusted and adjusted $p$-values. As seen in online Appendix IV.C, we draw the same conclusions if we adjust for both treatment arms (16 comparisons).

\section{A. Impacts on Employment/Occupational Choice}

To measure occupational and earnings impacts, at each endline we asked respondents whether they had engaged in 22 occupations, from farming to petty business, trades, and formal jobs. For each one, we collected self-reported hours and net earnings in both the last week and the week prior. With two endline surveys this gives us four weeks of employment data per person. People reported 0 to 3 occupations, with an average of 0.75 (1.13 among those reporting any). We calculate total hours and earnings across all occupations each week, and estimate treatment effects on the average of the two weeks of data.

Table 6 reports ITT estimates on the overall family index, the components of the index, as well as a set of other economic outcomes measures in the survey that are of interest but do not fit conceptually in employment/occupational choice and income. We adjust $p$-values for family indexes but do not adjust $p$-values for the components of indexes, or for other outcomes, and so those results must be taken with some caution, and be viewed as more suggestive and descriptive in nature. We report on 
Table 6-Impacts of the Job OfFer and Entrepreneurship Program on Employment and Income

\begin{tabular}{|c|c|c|c|c|c|c|c|c|c|}
\hline \multirow[b]{3}{*}{ Outcome } & \multirow[b]{3}{*}{$\begin{array}{c}\text { Control } \\
\text { mean } \\
(1)\end{array}$} & \multicolumn{8}{|c|}{ ITT estimate $(N=1,587)$} \\
\hline & & \multicolumn{3}{|c|}{ Job offer } & \multicolumn{3}{|c|}{ Entrepreneurship program } & \multicolumn{2}{|c|}{ Job-Entrepreneu } \\
\hline & & $\begin{array}{l}\text { Coeff. } \\
(2)\end{array}$ & $\begin{array}{l}\text { SE } \\
(3)\end{array}$ & $\begin{array}{l}\text { Adj. } p \text {-val. } \\
\text { (4) }\end{array}$ & $\begin{array}{l}\text { Coeff. } \\
(5)\end{array}$ & $\begin{array}{l}\text { SE } \\
(6)\end{array}$ & $\begin{array}{l}\text { Adj. } p \text {-val. } \\
\text { (7) }\end{array}$ & $\begin{array}{c}\text { Coeff. } \\
(8)\end{array}$ & $\begin{array}{l}\text { SE } \\
(9)\end{array}$ \\
\hline $\begin{array}{l}\text { Employment and occupational } \\
\text { choice, } z \text {-score }\end{array}$ & -0.04 & 0.078 & {$[0.074]$} & 0.909 & 0.040 & {$[0.076]$} & 0.849 & 0.038 & {$[0.079]$} \\
\hline Hours work/week, past two weeks & 26.39 & 0.997 & {$[1.895]$} & & 3.506 & {$[1.892]$} & & -2.509 & {$[2.010]$} \\
\hline Factory labor & 7.46 & 3.017 & {$[1.380]$} & & -4.104 & {$[1.169]$} & & 7.122 & {$[1.287]$} \\
\hline Farm wage labor & 3.07 & 1.817 & {$[0.914]$} & & -1.480 & {$[0.744]$} & & 3.297 & {$[0.865]$} \\
\hline Smallholder farming & 0.82 & -0.258 & {$[0.323]$} & & 1.480 & {$[0.398]$} & & -1.738 & {$[0.430]$} \\
\hline Petty business & 4.04 & -0.878 & {$[0.978]$} & & 5.381 & {$[1.379]$} & & -6.259 & {$[1.353]$} \\
\hline Skilled trades & 1.59 & -0.736 & {$[0.449]$} & & -0.576 & {$[0.483]$} & & -0.160 & {$[0.408]$} \\
\hline Casual nonfarm labor & 2.18 & -0.954 & {$[0.568]$} & & 0.746 & {$[0.770]$} & & -1.700 & {$[0.662]$} \\
\hline Low-skill salaried labor & 4.19 & 0.064 & {$[1.095]$} & & -0.412 & {$[0.956]$} & & 0.476 & {$[0.984]$} \\
\hline Medium-skill salaried labor & 1.21 & -0.415 & {$[0.420]$} & & 1.604 & {$[0.590]$} & & -2.018 & {$[0.545]$} \\
\hline Other work & 2.27 & -0.085 & {$[0.694]$} & & 0.489 & {$[0.738]$} & & -0.574 & {$[0.800]$} \\
\hline Unemployed in past two weeks & 0.34 & -0.013 & {$[0.033]$} & & -0.082 & {$[0.032]$} & & 0.068 & {$[0.034]$} \\
\hline SD of hours/week & 16.44 & -1.306 & {$[1.342]$} & & 3.949 & {$[1.476]$} & & -5.254 & {$[1.458]$} \\
\hline Income, $z$-score & -0.01 & 0.014 & {$[0.052]$} & 0.949 & 0.150 & {$[0.058]$} & 0.029 & -0.135 & {$[0.057]$} \\
\hline Weekly earnings, $2010 \mathrm{birr}$ & 34.23 & 3.049 & {$[4.479]$} & & 12.005 & {$[5.463]$} & & -8.956 & {$[5.426]$} \\
\hline Earnings per hour, 2010 birr & 1.46 & -0.020 & {$[0.186]$} & & 0.153 & {$[0.200]$} & & -0.173 & {$[0.200]$} \\
\hline SD of weekly earnings & 56.01 & 4.107 & {$[7.600]$} & & 3.769 & {$[8.263]$} & & -0.079 & {$[0.067]$} \\
\hline $\begin{array}{l}\text { Household-level durable } \\
\text { consumption assets, } z \text {-score }\end{array}$ & 0.07 & -0.071 & {$[0.069]$} & & 0.009 & {$[0.067]$} & & -56.289 & {$[33.861]$} \\
\hline $\begin{array}{l}\text { Household-level nondurable } \\
\text { consumption, } 2010 \text { birr }\end{array}$ & 664.46 & 20.548 & {$[34.653]$} & & 76.837 & [35.492] & & -0.282 & {$[0.074]$} \\
\hline $\begin{array}{l}\text { Household-level durable } \\
\text { productive assets, } z \text {-score }\end{array}$ & -0.12 & 0.049 & {$[0.068]$} & & 0.331 & {$[0.077]$} & & -0.282 & {$[0.074]$} \\
\hline
\end{tabular}

Notes: Columns 2 to 5 report the results of an OLS regression of each outcome on treatment indicators, baseline covariates, and cohort-gender fixed effects. Survey responses at 11 and 13 months are pooled. Standard errors are robust and clustered by respondent. $p$-values are adjusted for family outcomes using the Westfall-Young approach described in Section V. Some outcomes contain fewer observations than the listed number of observations because a very small number of respondents were not asked certain questions.

${ }^{\dagger}$ Denotes outcome variables that were measured during only one of the endline surveys.

them mainly to help understand the substantive nature of the indexes and interpret what changes may mean.

There was no change in total hours worked per week among those offered an industrial job, but occupations shift. Factory and commercial farm labor increased while petty business, casual labor, and other activities decreased. Those assigned to the entrepreneurship program, meanwhile, increased total hours worked by 3.5 per week (significant at the 10 percent level only) and shifted their time toward smallholder farming and petty business, as well as medium-skilled salaried labor (e.g., white collar jobs). ${ }^{33}$ The difference between the employment and occupational

\footnotetext{
${ }^{33}$ A family index of hours worked, unemployment, and the standard deviation of hours does not rise significantly because the increase in the standard deviation of hours enters negatively into the index. If we exclude or reverse the direction of this volatility measure, the rise in employment is highly significant. In online Appendix IV.B, we display histograms of average weekly hours and estimated earnings in the past month for the job offer and control groups. They are broadly similar.
} 
choice index in the entrepreneurship arm and in the job offer arm is less than 0.04 standard deviations and statistically not significant. ${ }^{34}$

\section{B. Impacts on Income}

We use three measures of income. One is the sum of weekly cash earnings across the 22 occupations. ${ }^{35}$ Earnings are seasonal and do not reflect home production, so we also consider two measures of permanent income reported by the household: an index of 32 durable consumption assets (e.g., housing quality, furniture) and the value of nondurable consumption in the previous 4 weeks via an abbreviated consumption module of 82 items. ${ }^{36}$

Table 6 shows that on balance the factory job offer seems to have no significant effect on income by any of the three measures, and a family index of the three increases only 0.014 standard deviations. ${ }^{37}$ These income measures tend to be skewed and highly variable, however, and so our estimates are imprecise. Thus, while the average effect is close to zero, the confidence interval on income includes moderate increases and decreases in income from the industrial job offer.

Even if the income effect after a year is negligible, the job offer could have still had an important impact on annual income by ending lengthy unemployment spells. Several results indicate this was not the case. One is that two of our three income measures (consumption and assets) are measures of permanent income, and so we would expect them to reflect large recent shocks, even if temporary. Moreover, if we use the survey data to estimate total annual income, we do not see any evidence of an increase.

The entrepreneurship program has a sizable effect on income, however, an impact that seems to be driven by the small business rather than a direct wealth effect of the grant, as the impact shows up in earnings more than assets and consumption. Weekly earnings in the entrepreneurship arm are 12 birr higher than the control group. In absolute terms this is roughly $\$ 1$ per week $(\$ 3.4 \mathrm{PPP})$, and in relative terms this is a large effect - a one-third increase in earnings for otherwise very poor young people.

If we assume this earnings gain lasted the whole year, those assigned to the entrepreneurship program earned about $\$ 52$ more since baseline-about 16 percent of the full grant, or 32 percent of the amount they said they initially invested. If we deduct compensation for added hours worked, these figures fall to 7 percent and

\footnotetext{
${ }^{34}$ The employment family index does not include information on general time use or school enrollment. We measured these in the survey for exploratory purposes, however, and report impacts in online Appendix IV.B. Not surprisingly, assignment to industrial work or the entrepreneurship program had little impact on time use, whether commute time (about 4 hours a week) or chores (20 hours on average per week). Those assigned to the entrepreneurship program report 3.6 fewer leisure hours per week compared to the control group (significant at the 5 percent level). School enrollment is 3.2 percentage points lower among those assigned to a job, about half the control mean (though significant at only the 10 percent level).

${ }^{35}$ As a check against this weekly and activity-based measure, we also ask respondents to estimate their total cash earnings in the past four weeks. The treatment effects are similar.

${ }^{36}$ See Beegle et al. (2012) for this approach. This abbreviated measure likely understates total consumption by excluding durable asset use and less common purchases. We do not have price data for valuing durables.

${ }^{37} \mathrm{We}$ also ask about savings flows in the past month and see no evidence of an increase (see online Appendix IV.D). Including this in the income index has no effect on our conclusions.
} 
Table 7-Heterogeneity in Treatment Effects by Baseline Earnings Potential

\begin{tabular}{|c|c|c|}
\hline \multirow[b]{2}{*}{ Outcome } & \multicolumn{2}{|c|}{ Dependent variable $(N=1,587)$} \\
\hline & $\begin{array}{c}\text { Working in } \\
\text { industrial firm } \\
(1)\end{array}$ & $\begin{array}{l}\text { Weekly } \\
\text { earnings } \\
(2)\end{array}$ \\
\hline Assigned to job offer $(a)$ & $\begin{array}{c}0.103 \\
{[0.038]}\end{array}$ & $\begin{array}{c}10.532 \\
{[5.375]}\end{array}$ \\
\hline Job $\times$ above median earnings potential $(b)$ & $\begin{array}{c}0.012 \\
{[0.053]}\end{array}$ & $\begin{array}{r}-11.493 \\
{[8.558]}\end{array}$ \\
\hline Assigned to entrepreneurship program & $\begin{array}{c}-0.151 \\
{[0.031]}\end{array}$ & $\begin{array}{l}10.393 \\
{[6.053]}\end{array}$ \\
\hline Entrepreneur $\times$ above median earnings potential & $\begin{array}{c}0.061 \\
{[0.044]}\end{array}$ & $\begin{array}{c}4.355 \\
{[9.526]}\end{array}$ \\
\hline Impact of job if above median earnings potential $(a+b)$ & $\begin{array}{c}0.115 \\
{[0.037]}\end{array}$ & $\begin{array}{r}-0.962 \\
{[6.448]}\end{array}$ \\
\hline Impact of entrepreneurship program if above median earnings potential $(a+b)$ & $\begin{array}{r}-0.090 \\
{[0.032]}\end{array}$ & $\begin{array}{c}14.748 \\
{[7.693]}\end{array}$ \\
\hline
\end{tabular}

Notes: See footnote 40 for construction of the indicator of above median earnings potential. Survey responses at 11 and 13 months are pooled. Standard errors are robust and clustered at the individual level.

13 percent. ${ }^{38}$ These are not necessarily high returns, especially when we consider that the recipients also received training in addition to the capital, though the returns are higher when using our estimated measures of annual hours worked and total income: about 16 percent of the grant after accounting for added hours worked.

Looking at the income family index, the increase in income in the entrepreneurship arm is significant at the 5 percent level after adjusting for 8 comparisons. Note that it is only significant at the 10 percent level when we adjust for 16 comparisons (across outcomes and treatment arms). Furthermore, Table 6 shows that the job arm earns 0.14 standard deviations less than the entrepreneurship arm, significant at the 10 percent level.

A job offer does not lead to less volatile earnings or work hours. If we take the standard deviation of weekly work hours or weekly earnings for the four weeks of data available, we see no evidence of a significant decrease from a job-offer (indeed the point estimate on the standard deviation of earnings is positive). ${ }^{39}$ The cash grant, meanwhile, increases the standard deviation of weekly work hours and weekly earnings.

Heterogeneous Employment and Earnings Impacts.-The zero average treatment effect on earnings conceals some heterogeneity, reported in Table 7. We divide the sample into two groups - those with high and low outside earnings potential—constructed using an index of baseline characteristics that predicts endline earnings in the absence of treatment. ${ }^{40}$ We interact the indicator for above median earnings

\footnotetext{
${ }^{38}$ Entrepreneurship recipients work 3.5 more hours per week, valued at 5 birr per week at the average wagefrom Table 6 . We subtract this from the 12 birr per week.

${ }^{39}$ See online Appendix IV.B for histograms of average weekly hours and estimated earnings in the past month for the job offer and control groups. They are broadly similar.

${ }^{40}$ We regress the control group's endline earnings on baseline covariates and predict an outcome. To avoid endogenous stratification, we do this for each control group member individually, excluding their own observation
} 
potential with treatment. As a result, the coefficient on assignment to the job offer can be interpreted as the treatment effect on applicants with characteristics associated with below median earnings opportunities. The sum of this coefficient and the coefficient on the interaction (reported at the base of the table) can be interpreted as the effect of a job offer on applicants with characteristics associated with above median earnings. This heterogeneity analysis was not prespecified and so must be taken with some caution, but also happens to be the only heterogeneity we analyzed.

Regardless of their earnings prospects, those assigned to job offer are about 10 percentage points more likely to be working in an industrial firm at endline (column 1 of Table 8). The job offer weakly increases earnings for applicants with low predicted outside earning potential, but has no apparent effect on applicants with high outside earning potential (column 2 of Table 8). The difference (the interaction term) is not statistically significant. Substantively, however, the figures are large. At endline, control group members with below median earnings potential earned just 11.6 birr per week on average (compared to 34 birr per week for the full control group). Thus, the 10.5 birr treatment effect on low types is nearly a doubling in earnings. This comes almost entirely for an increase in the hours of work available, not the wage.

While the wide standard errors suggest caution, these patterns imply that people with poor self-employment or wage prospects can increase their earnings in the industrial sector because it offers them more regular employment. For people with stronger self-employment and wage prospects, however, accepting a job can have persistent effects on occupational choice a year later, even if the quality of the match is poor. ${ }^{41}$

Interestingly, the entrepreneurship program seems to increase earnings among both high- and low-predicted outside earning potential. This could imply that low outside earning potential is driven by liquidity and credit constraints rather than innate ability.

\section{Impacts on Physical Health}

Table 8 reports impacts on our measures of health and well-being. One of the main measures of physical health is self-reported ability to perform 5 activities of daily life, or ADLs: walk $2 \mathrm{~km}$, work outside on your feet for a full day, carry a 20 liter carton of water 20 meters, do usual daily activities, and standing at workbench working for 6-8 hours. ${ }^{42}$ Each is measured on a 0-3 scale running from unable (0), great difficulty (1), slight difficulty (2), and easily (3). ADL measures are widely used in studies of labor supply or health and economic development in

from the fitted model (see Abadie, Chingos, and West 2014 for a description of this "leave-one-out" method). We then use the estimated coefficients from the full control group to predict earnings potential for the treatment group. We use these predictions to create an indicator for above- and below-median earnings potential, and interact this indicator with indicators for assignment to treatments.

${ }^{41}$ One cautionary note: it is possible that the "high" types who stay and have lower earnings than their peers in the control group are actually low ability in some unobserved way, and that their low earnings reflect their low marginal product. While possible, it is worth noting we have an unusually rich set of baseline covariates going far beyond the usual Mincerian regressions, including time preferences, personality traits, work histories, mental abilities (such as executive function), and other covariates that are typically strong determinants of lifetime earnings potential.

${ }^{42}$ We adapted the five questions from existing ADL instruments to the context in Ethiopia. We are not aware of a standardized or validated ADL instrument for either Ethiopia or sub-Saharan Africa. 
Table 8-Impacts of the Job Offer and Entrepreneurship Program on Physical and Mental Health

\begin{tabular}{|c|c|c|c|c|c|c|c|c|c|}
\hline \multirow[b]{3}{*}{ Outcome } & \multirow{3}{*}{$\begin{array}{c}\text { Control } \\
\text { mean } \\
(1)\end{array}$} & \multicolumn{8}{|c|}{ ITT estimate $(N=1,587)$} \\
\hline & & \multicolumn{3}{|c|}{ Job offer } & \multicolumn{3}{|c|}{ Entrepreneurship program } & \multicolumn{2}{|c|}{ Job-Entrepreneur } \\
\hline & & $\begin{array}{l}\text { Coeff. } \\
(2)\end{array}$ & $\begin{array}{l}\text { SE } \\
(3)\end{array}$ & $\begin{array}{l}\text { Adj. } p \text {-val. } \\
\text { (4) }\end{array}$ & $\begin{array}{l}\text { Coeff. } \\
(5)\end{array}$ & $\begin{array}{l}\text { SE } \\
(6)\end{array}$ & $\begin{array}{l}\text { Adj. } p \text {-val. } \\
\text { (7) }\end{array}$ & $\begin{array}{c}\text { Coeff. } \\
(8)\end{array}$ & $\begin{array}{l}\text { SE } \\
(9)\end{array}$ \\
\hline Physical health, $z$-score & 0.06 & -0.193 & {$[0.066]$} & 0.020 & -0.098 & {$[0.062]$} & 0.343 & -0.097 & {$[0.070]$} \\
\hline $\begin{array}{l}\text { Ability to do activities of daily life } \\
(0-15)\end{array}$ & 14.07 & -0.274 & {$[0.125]$} & & -0.240 & {$[0.128]$} & & -0.039 & {$[0.136]$} \\
\hline Disability & 0.04 & 0.033 & {$[0.015]$} & & 0.017 & {$[0.014]$} & & 0.017 & {$[0.015]$} \\
\hline Subjective health assessment $(0-10)$ & 8.91 & -0.233 & {$[0.104]$} & & 0.001 & {$[0.104]$} & & -0.236 & {$[0.111]$} \\
\hline $\begin{array}{l}\text { Subjective health assessment, } \\
5 \text { years from now }(0-10)\end{array}$ & 9.67 & -0.181 & {$[0.060]$} & & 0.000 & {$[0.056]$} & & -0.182 & {$[0.062]$} \\
\hline $\begin{array}{l}\text { Mental health and subjective well-being, } \\
z \text {-score }\end{array}$ & -0.11 & 0.072 & {$[0.071]$} & 0.909 & 0.228 & {$[0.065]$} & 0.001 & -0.155 & {$[0.068]$} \\
\hline Depression symptoms $(0-27)$ & 2.54 & -0.088 & {$[0.219]$} & & -0.278 & {$[0.211]$} & & 0.189 & {$[0.210]$} \\
\hline $\begin{array}{l}\text { Aggressive and antisocial behaviors } \\
(0-27)\end{array}$ & 1.92 & -0.058 & {$[0.127]$} & & -0.071 & {$[0.123]$} & & 0.013 & {$[0.126]$} \\
\hline Anxiety symptoms $(0-21)$ & 2.03 & 0.053 & {$[0.197]$} & & -0.279 & {$[0.183]$} & & 0.332 & {$[0.189]$} \\
\hline Level of financial anxiety $(0-12)$ & 1.59 & -0.071 & {$[0.136]$} & & -0.297 & {$[0.128]$} & & 0.226 & {$[0.133]$} \\
\hline Subjective well-being $(0-10)$ & 4.14 & 0.193 & {$[0.111]$} & & 0.377 & {$[0.108]$} & & -0.182 & {$[0.109]$} \\
\hline $\begin{array}{l}\text { Subjective well-being, } 5 \text { years from now } \\
(0-10)\end{array}$ & v 7.57 & 0.093 & {$[0.122]$} & & 0.340 & {$[0.120]$} & & -0.247 & {$[0.120]$} \\
\hline
\end{tabular}

Notes: Columns 2 to 5 report the results of an OLS regression of each outcome on treatment indicators, baseline covariates, and cohort-gender fixed effects. Survey responses at 11 and 13 months are pooled. Standard errors are robust and clustered by respondent. $p$-values are adjusted for family outcomes using the Westfall-Young approach described in Section V. Some outcomes contain fewer observations than the listed number of observations because a very small number of respondents were not asked certain questions.

developed and developing countries, including in Africa, and they have been tested for consistency across tests, interviewers, and skills. ${ }^{43}$

We also code an indicator for a "disability," which we define as reporting "great difficulty" or "unable" on at least two ADLs. Four percent of the control group report such a disability at endline. Otherwise, most people in our sample are young and in excellent health, and so report nearly perfect ADLs (14 of a potential score of 15 on average).

Finally, we collect a subjective measure of health using Cantril's Self-Anchoring scale, a life evaluation approach commonly used in Gallup polls and social science studies (e.g., Kahneman and Deaton 2010). We gave respondents a picture of three ladders, with ten rungs each, where the top rung represented the best health and the lowest the worst health.

An industrial job is associated with a 0.27 decrease in the ADL index and a 0.23 decline in subjective health evaluations. While these declines are small relative to the means, they seem to be driven by a few people reporting serious disabilities. The disability rate rises 3.3 percentage points among those offered an industrial job, nearly doubling the risk of injury. A family index of the health measures suggests job recipients report a 0.19 standard deviation decline in health, and the effect is

\footnotetext{
${ }^{43}$ See, for example, Ware et al. (1980) and Strauss and Thomas (2007). ADLs are commonly used in household surveys and program evaluations because they are more common than morbidity and mortality in small or short-run samples, and because measures such as days ill or away from work may be endogenous to labor supply decisions.
} 
TABle 9-IV Estimates of the Impacts of an Extra Month in an Industrial Job

\begin{tabular}{|c|c|c|c|}
\hline \multirow[b]{2}{*}{ Outcome } & \multirow[b]{2}{*}{$\begin{array}{c}\text { Control mean } \\
(1)\end{array}$} & \multicolumn{2}{|c|}{$\begin{array}{c}\text { Months in an } \\
\text { industrial firm since } \\
\text { baseline }(N=1,587)\end{array}$} \\
\hline & & $\begin{array}{l}\text { CATE } \\
(2)\end{array}$ & $\begin{array}{l}\text { SE } \\
(3)\end{array}$ \\
\hline Hours work/week, past month & 26.39 & 0.389 & {$[0.702]$} \\
\hline Weekly earnings, 2010 birr & 34.23 & 1.186 & {$[1.6745]$} \\
\hline Earnings per hour, 2010 birr & 1.46 & -0.007 & {$[0.058]$} \\
\hline $\mathrm{HH}$ consumption durable assets, $z$-score ${ }^{\mathrm{y}}$ & 0.07 & -0.024 & {$[0.022]$} \\
\hline HH nondurable consumption, $z$-score & 665.05 & 7.889 & {$[13.057]$} \\
\hline Activities of daily life $(0-15)$ & 14.07 & -0.106 & {$[0.049]$} \\
\hline Disability & 0.04 & 0.013 & {$[0.006]$} \\
\hline
\end{tabular}

Notes: Columns 2 and 3 report the results of two-stage least squares regression of outcomes on months employed in an industrial job since baseline, an entrepreneurship program assignment indicator, baseline covariates, and cohort-gender fixed effects, instrumented using random assignment to the factory job. Coefficients on the grant and all covariates are omitted. Table 3 displays first-stage results. Survey responses at 11 and 13 months are pooled. Standard errors are robust and clustered by respondent.

${ }^{\mathrm{y}}$ Denotes outcome variables that were measured during only endline survey.

significant at the 1 percent level using conventional $p$-value cutoffs and at the 5 percent level after adjusting for eight multiple comparisons (Figure 1).

Our qualitative interviews suggest a number of common ailments, especially repetitive stress injuries from standing or repeated tasks, or respiratory problems due (people report) to dust, particulates, or chemical fumes. We do not know if these represent chronic or temporary problems, but there is some suggestion they may be permanent problems. We asked people to rate their subjective health five years from now on the same ladder. The control mean rose, but the treatment effect is similar to the subjective health today.

These results are also robust to different ways of coding "disabilities" (online Appendix IV.E). They are also robust to excluding any one firm from the estimates, although disabilities seem to be highest in the horticultural firm and shoe factory (online Appendix IV.H).

Table 9 reports the CATEs for main outcomes. The clearest impact is on health. Each additional week in an industrial firm is associated with about a 1.1 percentage point increase in a serious difficulty performing two or more standard activities of daily life.

We have to take these results with some caution. First, only a small absolute number of people report "great difficulty" at an ADL: 10 in the control group and 15 in the job offer arm. Second, these are self-reported data and in principle measurement error could be correlated with treatment. ${ }^{44}$ Unfortunately, we do not have

\footnotetext{
${ }^{44}$ Self-perceptions of health might be affected endogenously by work experiences, for example. Our disability treatment effect, for instance, becomes smaller and no longer statistically significant if we exclude either the "working outdoors for a full day" or the "standing all day at a workbench" components. These are the components that are the largest and most statistically significant. While this may be worrisome, it is worth noting that if we use the "some difficulty" threshold for a disability indicator, the largest and most significant components are "carrying 20 liters" and "performing daily activities," and the overall impact of the job offer on disability is statistically significant and robust to excluding "working outdoors for a full day" or the "standing all day at a workbench" components. See online Appendix X.E for this sensitivity analysis.
} 
Table 10-Self-Reported WorkPlace Conditions: Treatment Effects and Correlates of Endline WORKPLACE

\begin{tabular}{|c|c|c|c|c|c|c|c|c|c|}
\hline \multirow[b]{3}{*}{ Outcome } & \multirow{3}{*}{$\begin{array}{c}\text { Control } \\
\text { mean } \\
(1)\end{array}$} & \multicolumn{4}{|c|}{$\begin{array}{l}\text { ITT estimate } \\
(N=1,587)\end{array}$} & \multicolumn{4}{|c|}{$\begin{array}{l}\text { OLS coeff. on indicator for } \\
\text { industrial work at endline }\end{array}$} \\
\hline & & \multicolumn{2}{|c|}{ Job offer } & \multicolumn{2}{|c|}{ Entrepreneurship } & \multicolumn{2}{|c|}{$\begin{array}{l}\text { Full sample } \\
(N=829)\end{array}$} & \multicolumn{2}{|c|}{$\begin{array}{c}\text { Nonzero work } \\
\text { hours }(N=532)\end{array}$} \\
\hline & & $\begin{array}{l}\text { Coeff. } \\
(2)\end{array}$ & $\begin{array}{l}\text { SE } \\
(3)\end{array}$ & $\begin{array}{l}\text { Coeff. } \\
(4)\end{array}$ & $\begin{array}{l}\text { SE } \\
(5)\end{array}$ & $\begin{array}{l}\text { Coeff. } \\
(6)\end{array}$ & $\begin{array}{l}\text { SE } \\
(7)\end{array}$ & $\begin{array}{l}\text { Coeff. } \\
(8)\end{array}$ & $\begin{array}{l}\text { SE } \\
(9)\end{array}$ \\
\hline $\begin{array}{l}\text { Serious health risks at workplace } \\
(0-1)\end{array}$ & 0.14 & 0.078 & {$[0.033]$} & 0.005 & {$[0.032]$} & 0.279 & {$[0.040]$} & 0.297 & {$[0.054]$} \\
\hline $\begin{array}{l}\text { Need more safety equipment at } \\
\text { work }(0-1)\end{array}$ & 0.27 & 0.111 & {$[0.040]$} & -0.031 & {$[0.038]$} & 0.423 & {$[0.043]$} & 0.407 & {$[0.059]$} \\
\hline Poor air quality $(0-5)$ & 0.47 & 0.025 & {$[0.047]$} & -0.066 & {$[0.045]$} & 0.313 & {$[0.056]$} & 0.299 & {$[0.090]$} \\
\hline Very bad smells & 0.19 & 0.029 & {$[0.034]$} & -0.051 & {$[0.034]$} & 0.250 & {$[0.039]$} & 0.139 & {$[0.057]$} \\
\hline Dust & 0.35 & -0.030 & {$[0.041]$} & -0.031 & {$[0.041]$} & 0.044 & {$[0.045]$} & 0.043 & {$[0.064]$} \\
\hline Smoke from fire & 0.12 & -0.005 & {$[0.028]$} & 0.042 & {$[0.030]$} & -0.096 & {$[0.025]$} & -0.078 & {$[0.045]$} \\
\hline Smoke from machine & 0.08 & -0.014 & {$[0.020]$} & -0.034 & {$[0.020]$} & 0.092 & {$[0.026]$} & 0.051 & {$[0.034]$} \\
\hline Other chemicals or bad air quality & 0.14 & 0.061 & {$[0.031]$} & -0.044 & {$[0.030]$} & 0.374 & {$[0.038]$} & 0.355 & {$[0.052]$} \\
\hline Workplace conditions, $(0-8)$ & 5.23 & -0.043 & {$[0.143]$} & 0.357 & {$[0.147]$} & -0.804 & {$[0.155]$} & -0.763 & {$[0.211]$} \\
\hline Good physical comfort & 0.84 & -0.047 & {$[0.035]$} & -0.033 & {$[0.034]$} & -0.062 & {$[0.038]$} & -0.093 & {$[0.054]$} \\
\hline Temperature is comfortable & 0.76 & -0.050 & {$[0.038]$} & 0.043 & {$[0.037]$} & -0.266 & {$[0.043]$} & -0.296 & {$[0.058]$} \\
\hline Work hour control & 0.69 & 0.024 & {$[0.040]$} & 0.078 & {$[0.040]$} & -0.183 & {$[0.044]$} & -0.090 & {$[0.070]$} \\
\hline Easy to get time off & 0.73 & -0.049 & {$[0.038]$} & 0.069 & {$[0.039]$} & -0.260 & {$[0.043]$} & -0.185 & {$[0.064]$} \\
\hline Opportunity to learn skills & 0.42 & 0.054 & {$[0.042]$} & 0.068 & {$[0.044]$} & 0.212 & {$[0.044]$} & 0.256 & {$[0.067]$} \\
\hline Has enough space & 0.62 & 0.032 & {$[0.041]$} & 0.030 & {$[0.044]$} & -0.044 & {$[0.045]$} & -0.099 & {$[0.068]$} \\
\hline Can take short breaks & 0.64 & 0.020 & {$[0.042]$} & 0.027 & {$[0.042]$} & -0.160 & {$[0.044]$} & -0.165 & {$[0.067]$} \\
\hline Work is interesting & 0.52 & -0.026 & {$[0.044]$} & 0.085 & {$[0.045]$} & -0.046 & {$[0.046]$} & -0.095 & {$[0.070]$} \\
\hline
\end{tabular}

Notes: Treatment effects in columns 1 to 5 are calculated as in Tables 6 and 8 . The estimates in columns 6 to 9 come from an OLS regression of each outcome on an indicator for working in industrial employment in the past month for both the entire sample and for those with nonzero hours of work. In columns 8 and 9, we also include an indicator for working more than 15 hours in nonindustrial work in the past week.

objective tests of health or disability. Finally, note that the difference between the average health of the job offer arm and the health of the entrepreneurship arm is not statistically significant, as the entrepreneurship arm also experiences a small, statistically insignificant reduction in health. The general magnitude of the job treatment effect remains, but it loses its statistical significance. This may be because selfemployment carries its own occupational risks, or because (as we mention above) the results are based on a small number of extreme injuries.

Nonetheless, the results are consistent with worker's descriptions of factory workplace conditions. We asked survey respondents to describe the amenities and disamenities of their endline workplace, largely for descriptive purposes. Table 10 reports summary statistics, treatment effects, and correlations with endline employment status.

Fourteen percent of the control group reported serious health risks at their place of work, and this increased 7.8 percentage points in the job offer arm. Twenty-seven percent reported a need for greater safety equipment in their place of work, and this increased 11 percentage points in the job offer arm. These health concerns do not appear to be associated with air quality or general workplace comfort, since we see little effect of treatment on these measures. We see a weak treatment effect on complaints of chemical smells. We see no other statistically significant treatment effects of the job offer on other workplace conditions other than these health-related ones. 
These ITT estimates likely understate the disamenities of industrial work, given that most people assigned to industrial jobs quit the sector. Columns 6 to 9 of Table 10 report the results of a simple OLS regression of workplace conditions on an indicator for endline industrial work, controlling for baseline covariates, first on the full sample and then limiting the sample to those with nonzero hours of work. Working in an industrial job is associated with at least a 28 percentage point increase in perceived health risks (especially chemicals but also smoke), a more than 40 percentage point increase in the perception of a need for safety equipment, and at least a 35 percentage point increase in complaints of chemicals. In general, air quality and workplace comfort is moderately lower in industrial as opposed to other forms of work, even excluding the unemployed.

\section{Impacts on Mental Health and Happiness}

Table 8 also considers a number of self-reported facets of mental well-being. ${ }^{45} \mathrm{In}$ general, people report very few symptoms of depression or anxiety. We also asked people four questions about severe financial worries. These are also relatively rare, perhaps because many are young people living at home with lower middle class families, and generally have enough to eat. Finally, to measure subjective well-being (happiness) we used the same life evaluation ladder as with health, but where the top rung represented the best possible life and the lowest the worst possible.

We see no evidence of an effect of the job offer on mental health, and weak evidence of an increase in subjective well-being now (but not in five years). The entrepreneurship arm, however, led to small and statistically significant decreases in financial anxiety, as well as a rise in subjective well-being. There were also small declines in depression and anxiety symptoms. Overall, a family index of all these measures increase 0.23 standard deviations (significant at the 1 percent level using conventional thresholds and at the 5 percent level after we adjust for 8 outcomes).

\section{E. Impacts on Indirect Outcome Families}

In Table 11, we see no statistically significant changes in our secondary measures, which include firm attitudes (e.g., whether firms pay fair wages, or respect worker rights); social integration (including family, social, and community connectedness and trust); autonomy (including financial independence and freedom from coercion in the household); or noncognitive skills (including conscientiousness, self-esteem, and punctuality).

Online Appendix IV.G describes these measures in more detail, where none of the individual measures making up these family indices have a statistically significant treatment effect. We measured them in anticipation of low turnover and substantial effects of the job offer on occupations and earnings. Given the absence of a large

\footnotetext{
${ }^{45}$ We piloted several standard depression and anxiety questionnaires to determine what appeared to work best in our population, in part by ease of respondent understanding and in part by high levels of within-scale intercorrelations. For depression, we use the Patient Health Questionnaire (PHQ-9), a nine-item scale incorporating depression diagnostic criteria (Martin et al. 2006). To evaluate clinical anxiety and stress, we use the Generalized Anxiety Disorder-7 (GAD-7), a seven-item scale (Spitzer et al. 2006).
} 
Table 11-Treatment EfFects on Secondary Outcomes

\begin{tabular}{|c|c|c|c|c|c|c|c|c|c|}
\hline \multirow[b]{3}{*}{ Outcome } & \multirow{3}{*}{$\begin{array}{c}\text { Control } \\
\text { mean } \\
(1)\end{array}$} & \multicolumn{8}{|c|}{ ITT estimate $(N=1,587)$} \\
\hline & & \multicolumn{3}{|c|}{ Job offer } & \multicolumn{3}{|c|}{ Entrepreneurship program } & \multicolumn{2}{|c|}{$\begin{array}{c}\text { Job- } \\
\text { Entrepreneur }\end{array}$} \\
\hline & & $\begin{array}{l}\text { Coeff. } \\
(2)\end{array}$ & $\begin{array}{l}\text { SE } \\
(3)\end{array}$ & $\begin{array}{l}\text { Adj. } p \text {-val. } \\
\text { (4) }\end{array}$ & $\begin{array}{l}\text { Coeff. } \\
(5)\end{array}$ & $\begin{array}{l}\text { SE } \\
(6)\end{array}$ & $\begin{array}{l}\text { Adj. } p \text {-val. } \\
\text { (7) }\end{array}$ & $\begin{array}{l}\text { Coeff. } \\
(8)\end{array}$ & $\begin{array}{l}\text { SE } \\
(9)\end{array}$ \\
\hline $\begin{array}{l}\text { Anti-firm/pro-union attitudes, } \\
z \text {-score }\end{array}$ & 0.00 & 0.05 & {$[0.085]$} & 0.917 & -0.09 & {$[0.089]$} & 0.755 & 0.14 & {$[0.090]$} \\
\hline $\begin{array}{l}\text { Firms good for workers } \\
\text { and country }(0-24)\end{array}$ & 10.81 & 0.10 & {$[0.248]$} & & -0.41 & {$[0.257]$} & & 0.51 & {$[0.259]$} \\
\hline $\begin{array}{l}\text { Foreign firms good for country } \\
\quad(0-24)\end{array}$ & 9.81 & 0.39 & {$[0.258]$} & & -0.32 & {$[0.268]$} & & 0.72 & {$[0.268]$} \\
\hline Workers rights protected $(0-24)$ & 14.13 & -0.17 & {$[0.252]$} & & -0.04 & {$[0.269]$} & & -0.13 & {$[0.267]$} \\
\hline Pro-unions $(0-24)$ & 12.49 & -0.07 & {$[0.294]$} & & 0.35 & {$[0.320]$} & & -0.42 & {$[0.315]$} \\
\hline Social integration, $z$-score & 0.04 & 0.01 & {$[0.018]$} & 0.949 & 0.00 & {$[0.018]$} & 0.849 & 0.00 & {$[0.018]$} \\
\hline Family support $(0-15)$ & 12.31 & -0.01 & {$[0.210]$} & & -0.02 & {$[0.223]$} & & 0.01 & {$[0.223]$} \\
\hline Social support $(0-15)$ & 2.41 & -0.08 & {$[0.072]$} & & 0.00 & {$[0.069]$} & & -0.08 & {$[0.076]$} \\
\hline Community participation $(0-8)$ & 9.55 & 0.17 & {$[0.233]$} & & -0.13 & {$[0.229]$} & & 0.30 & {$[0.230]$} \\
\hline Trust $(0-12)$ & 3.40 & -0.15 & {$[0.151]$} & & 0.07 & {$[0.149]$} & & -0.22 & {$[0.152]$} \\
\hline Autonomy, $z$-score & 5.72 & 0.25 & [0.195] & 0.909 & 0.08 & {$[0.204]$} & 0.849 & 0.18 & {$[0.206]$} \\
\hline $\begin{array}{l}\text { Independent decision making } \\
(0-36)\end{array}$ & 0.05 & -0.06 & {$[0.064]$} & & -0.05 & {$[0.062]$} & & -0.01 & {$[0.060]$} \\
\hline $\begin{array}{l}\text { Involvement in spending } \\
\text { decisions }(0-10)\end{array}$ & 5.43 & 0.16 & {$[0.265]$} & & 0.29 & {$[0.262]$} & & -0.13 & {$[0.269]$} \\
\hline Money freedom $(0-12)$ & 4.25 & -0.02 & {$[0.209]$} & & -0.07 & {$[0.217]$} & & 0.06 & {$[0.224]$} \\
\hline Abuse received $(0-21)$ & 1.00 & -0.12 & {$[0.150]$} & & -0.17 & {$[0.136]$} & & 0.06 & {$[0.131]$} \\
\hline Noncognitive skills, z-score & 0.08 & -0.04 & {$[0.033]$} & 0.909 & 0.03 & {$[0.035]$} & 0.849 & -0.07 & {$[0.036]$} \\
\hline Locus of control (0-24) & 17.09 & -0.05 & {$[0.238]$} & & 0.22 & {$[0.254]$} & & -0.27 & {$[0.255]$} \\
\hline Self-esteem $(0-24)$ & 16.47 & -0.39 & {$[0.258]$} & & -0.11 & {$[0.276]$} & & -0.28 & {$[0.275]$} \\
\hline Patience (0-14) & 2.91 & -0.06 & {$[0.073]$} & & 0.08 & {$[0.078]$} & & -0.15 & {$[0.077]$} \\
\hline Risk aversion $(0-24)$ & 1.79 & 0.03 & {$[0.055]$} & & -0.02 & {$[0.058]$} & & 0.05 & {$[0.058]$} \\
\hline Self-control $(0-24)$ & 2.35 & -0.02 & {$[0.054]$} & & 0.02 & {$[0.056]$} & & -0.04 & {$[0.059]$} \\
\hline Punctuality $(0-15)$ & 11.04 & -0.24 & {$[0.168]$} & & -0.08 & {$[0.171]$} & & -0.16 & {$[0.172]$} \\
\hline
\end{tabular}

Notes: Columns 2 to 5 report the results of an OLS regression of each outcome on treatment indicators, baseline covariates, and cohort-gender fixed effects. Survey responses at 11 and 13 months are pooled with robust standard errors clustered by individual. $p$-values are adjusted for family outcomes using the Westfall-Young approach described in Section V.

direct effect of factory job offers on well-being, the absence of indirect effects is unsurprising. It is worth noting, however, that despite the relatively large effects of an entrepreneurship program on occupational choice and earnings, we see little effect on social integration or empowerment.

\section{F. Robustness and Sensitivity Analysis}

Table 12 reports sensitivity analysis for key outcomes. We report: pooled endlines using randomization inference (column 2), difference-in-difference effects (column 3), ITT effects averaging the 11- and 13-month outcomes (column 4), and conservative attrition scenarios (columns 5 to 7$).{ }^{46}$ We estimate attrition bounds by imputing outcomes for unfound individuals at different points of the observed outcome distribution, focusing on the cases that reduce program impacts. For positive

\footnotetext{
${ }^{46}$ The results are also highly robust to clustering standard errors by factory, though this is an unnecessary adjustment because of the individual-level randomization, and a potentially problematic one given the small number of clusters.
} 
Table 12-Sensitivity Analysis of Treatment Effects to Alternate Models and Missing Data SCENARIOS

\begin{tabular}{|c|c|c|c|c|c|c|c|}
\hline \multirow[b]{3}{*}{ Outcome } & \multicolumn{4}{|c|}{ ITT estimate under alternative models } & \multirow{2}{*}{\multicolumn{3}{|c|}{$\begin{array}{c}\text { Sensitivity of ITT to attrition } \\
\text { Impute missing dependent } \\
\text { variable with mean }+(-) \\
X \text { SD for missing control } \\
\text { (treatment) individuals }\end{array}$}} \\
\hline & \multirow{2}{*}{$\begin{array}{c}\text { Result from } \\
\text { Tables } 6 \\
\text { and } 8 \\
(1) \\
\end{array}$} & \multirow{2}{*}{$\begin{array}{l}\text { Random- } \\
\text { ization } \\
\text { inference } \\
(2) \\
\end{array}$} & \multirow{2}{*}{$\begin{array}{l}\text { Diff-in-diff } \\
\text { estimate } \\
(3)\end{array}$} & \multirow{2}{*}{$\begin{array}{l}\text { Average } 11 \text { - } \\
\text { and } 13 \text {-month } \\
\text { responses } \\
\text { (4) }\end{array}$} & & & \\
\hline & & & & & $\begin{array}{c}0.1 \mathrm{SD} \\
(5)\end{array}$ & $\begin{array}{l}0.25 \mathrm{SD} \\
(6)\end{array}$ & $\begin{array}{c}0.5 \mathrm{SD} \\
(7)\end{array}$ \\
\hline \multicolumn{8}{|l|}{ Treatment: Industrial job offer } \\
\hline $\begin{array}{l}\text { Working in any industrial } \\
\text { firm at endline }\end{array}$ & $\begin{array}{c}0.108 \\
{[0.034]}\end{array}$ & $\begin{array}{c}0.108 \\
{[0.033]}\end{array}$ & $\begin{array}{c}0.101 \\
{[0.027]}\end{array}$ & $\begin{array}{l}0.108 \\
{[0.035]}\end{array}$ & $\begin{array}{c}0.092 \\
{[0.033]}\end{array}$ & $\begin{array}{c}0.081 \\
{[0.033]}\end{array}$ & $\begin{array}{c}0.065 \\
{[0.033]}\end{array}$ \\
\hline $\begin{array}{l}\text { Weekly earnings, } 2010 \text { birr } \\
\text { (lower bound) }\end{array}$ & $\begin{array}{c}3.049 \\
{[4.479]}\end{array}$ & $\begin{array}{c}3.049 \\
{[5.317]}\end{array}$ & $\begin{array}{c}1.299 \\
{[4.525]}\end{array}$ & $\begin{array}{l}3.351 \\
{[4.615]}\end{array}$ & $\begin{array}{c}2.164 \\
{[4.152]}\end{array}$ & $\begin{array}{c}0.181 \\
{[4.163]}\end{array}$ & $\begin{array}{r}-3.126 \\
{[4.203]}\end{array}$ \\
\hline $\begin{array}{l}\text { Weekly earnings, } 2010 \text { birr } \\
\text { (upper bound) }\end{array}$ & & & & & $\begin{array}{c}-2.628 \\
{[4.954]}\end{array}$ & $\begin{array}{c}-0.928 \\
{[4.968]}\end{array}$ & $\begin{array}{c}1.905 \\
{[5.009]}\end{array}$ \\
\hline Disability & $\begin{array}{c}0.033 \\
{[0.015]}\end{array}$ & $\begin{array}{c}0.033 \\
{[0.015]}\end{array}$ & $\begin{array}{c}0.044 \\
{[0.016]}\end{array}$ & $\begin{array}{c}0.033 \\
{[0.015]}\end{array}$ & $\begin{array}{c}0.030 \\
{[0.014]}\end{array}$ & $\begin{array}{c}0.024 \\
{[0.014]}\end{array}$ & $\begin{array}{l}0.018 \\
{[.014]}\end{array}$ \\
\hline \multicolumn{8}{|l|}{ Treatment: Entrepreneur } \\
\hline $\begin{array}{l}\text { Working in any industrial } \\
\text { firm at endline }\end{array}$ & $\begin{array}{c}-0.121 \\
{[0.028]}\end{array}$ & $\begin{array}{c}-0.121 \\
{[0.032]}\end{array}$ & $\begin{array}{c}-0.136 \\
{[0.024]}\end{array}$ & $\begin{array}{c}-0.121 \\
{[0.029]}\end{array}$ & $\begin{array}{r}-0.106 \\
{[0.027]}\end{array}$ & $\begin{array}{c}-0.095 \\
{[0.027]}\end{array}$ & $\begin{array}{r}-0.078 \\
{[0.027]}\end{array}$ \\
\hline $\begin{array}{l}\text { Weekly earnings, } 2010 \text { birr } \\
\text { (lower bound) }\end{array}$ & $\begin{array}{l}12.005 \\
{[5.463]}\end{array}$ & $\begin{array}{l}12.005 \\
{[5.385]}\end{array}$ & $\begin{array}{l}11.931 \\
{[5.445]}\end{array}$ & $\begin{array}{l}12.164 \\
{[5.600]}\end{array}$ & $\begin{array}{l}10.090 \\
{[5.050]}\end{array}$ & $\begin{array}{c}8.202 \\
{[5.060]}\end{array}$ & $\begin{array}{c}5.055 \\
{[5.093]}\end{array}$ \\
\hline $\begin{array}{l}\text { Subjective well-being, now } \\
\text { compared to one year ago }\end{array}$ & $\begin{array}{c}0.239 \\
{[0.071]}\end{array}$ & $\begin{array}{c}0.239 \\
{[0.076]}\end{array}$ & $\begin{array}{c}0.111 \\
{[0.094]}\end{array}$ & $\begin{array}{c}0.234 \\
{[0.073]}\end{array}$ & $\begin{array}{c}0.206 \\
{[0.065]}\end{array}$ & $\begin{array}{c}0.176 \\
{[0.065]}\end{array}$ & $\begin{array}{c}0.127 \\
{[0.066]}\end{array}$ \\
\hline Observations & 1,587 & 1,587 & 1,587 & 835 & 1,841 & 1,841 & 1,841 \\
\hline
\end{tabular}

Notes: Column 1 replicates the main tables. Column 2 uses randomization inference. Column 3 calculates difference-in-difference effects where baseline data are available. Column 4 averages instead of pooling the 11- and 13-month survey outcomes, so that there is one observation per person and down weights respondents only found in one endline. Columns 5-7 impute the mean of the control (treatment) group plus (minus) " $X$ " standard deviations of the group's distribution (SD), for $X=0.1,0.25,0.5$. All regressions include a vector of baseline covariates and gender-cohort fixed effects. Some outcomes contain fewer observations than the listed number of observations because a very small number of respondents were not asked certain questions. Standard errors are robust.

outcomes, we impute the observed mean plus $x$ standard deviations of the distribution for the control group; and for the treatment group, we impute the observed treatment mean minus $x$ standard deviations of the distribution, for $x=0.1,0.25$, and 0.5. In general, treatment effects are robust to all specifications. The increase in disability risk among the job arm and the increase in income in the entrepreneurship arm are smaller and less precise under extreme attrition scenarios. The direction of these effects and qualitative findings are unchanged, even in the worst-case scenarios. ${ }^{47}$

\section{Discussion and Conclusions}

Overall, the results suggest that industrial firms in Ethiopia paid no better than worker's informal alternatives, so that most workers were at best indifferent between these forms of work. This suggests a formal and informal labor market that was more fluid and competitive than we expected, at least for the young, unskilled, and capital-poor. When these young people's constraints on self-employment were

\footnotetext{
${ }^{47}$ Online Appendix IV.H also reports firm-by-firm treatment effects and illustrates robustness to omitting one firm at a time. It also shows that effects are similar by gender.
} 
lifted, however, they avoided industrial work and tended to start small but sustainable microenterprises that had raised their meager incomes by a third a year later. We see no evidence that entrepreneurship is undesirable or increases income risktwo of the most common charges levied against self-employment. The existence of competitive labor markets and subsistence-level industrial jobs would seem innocuous if not for evidence of adverse health effects of industrial work.

\section{A. Why Did People Take Poorly Paid, Hazardous Jobs?}

There are only a small number of possible explanations. One is that the severity of the health risks were not apparent to applicants, or even to active industrial workers themselves, and so they did not demand a compensating wage differential. A second possibility is a learning and matching story, where industrial jobs pay a compensating differential (or are otherwise worthwhile) for some, but that workers need to learn about their own nature or the nature of the work through the process of working (i.e., learning and matching). A third possibility is that firms screen and match workers only after they join the firm, promoting good matches and terminating bad ones. A final possibility is a smoothing shocks story, where industrial jobs do not pay a compensating differential when informal work is available, but are available during informal unemployment spells and other shocks. All but the last one require some kind of imperfect information.

We do not have the data or research design to test these alternatives formally. Eight cohorts in five firms do not offer enough variation or power to conduct a formal analysis, as the relevant number of firm and environmental factors exceeds the number of cohorts. Nonetheless, a combination of manager and worker interviews, patterns of treatment effects, and analysis of worker reports suggest that firms seldom screened, and workers generally understood the health risks, but that they took jobs anyway, often temporarily, to smooth consumption or to learn their fit with the position.

Imperfect Information about Health Risks.-We do not have baseline data on expectations of health risks but, as reported in Table 10, we asked the sample to describe their workplace conditions at endline. Factory and commercial farm workers were significantly more likely to see their workplace as risky and in need of greater safety protection than provided.

We see no evidence that people updated their beliefs about the harmfulness of factory work as a result of the treatment, however. The "attitudes to firms" index in Table 11 includes one health-related attitudinal question: whether "factories provide an environment that will not cause injuries or longer term health problems." On a 0 to 4 scale, the control group reported 1.99 on average. The ITT coefficient (and standard deviation) on the job offer was just $0.16(0.10)$, and the CATE for months in formal work was 0.05 (0.034). If workers learned of risks on the job, we would have expected a larger and more robust estimate.

Screening and Matching.-We can eliminate the screening and matching explanation simply based on how the firms appear to function. In models by Jovanovic 
(1979) and others, labor turnover is driven by imperfect information, as firms only learn about workers and their match quality (productivity) by hiring them. Workers apply where they may be a poor match, and firms hire more workers than needed. Employers reward good matches with higher wages or promotions and fire the others. If there are regulatory or other barriers to firing, then poor matches could be offered lower wages or unpleasant working conditions in the hopes they quit. One prediction would be a tenure premium: a steep earnings-experience relationship, not due to any direct causality in the form of experience leading to higher productivity and earnings, but rather from a correlation as those who are observed to stay in the firm for longer are the better, more productive matches for these industrial jobs.

We see little evidence in Ethiopia to suggest this screening mechanism explains our findings. In the five firms we worked with (and the many other firms we interviewed as candidates), none of the management described screening employees in this way. There was typically limited room for advancement, especially for women who made up the majority of our sample. There were also few regulatory barriers to firing workers. In general, firm managers were puzzled and dismayed by the high levels of turnover, and would have preferred to see all of the applicants stay.

The managers we interviewed also made efforts to add nonwage benefits, such as offering free transport, free clinics, and in some cases a free meal at a canteen. They appeared less likely to raise wages, however, and indeed often failed to keep pace with inflation and keep real wages constant. The reasons for not paying higher wages were hard to discern, and we gained a range of impressions from the many firms we interviewed: a belief that higher wages would not be profit-maximizing; a belief they might be but cash flow problems at the firm level made a higher wage bill impossible; and a tendency to money illusion, or thinking about wages in nominal terms and failing to keep pace with inflation. ${ }^{48}$

We do see a slight rising wage profile over time among the workers who stayed in industrial jobs, but the gains are not dramatic. In online Appendix IV.I, we regress endline earnings on a Mincerian-style set of baseline covariates, including of age, gender, health, education, and work experience. In no instance is prior industrial experience associated with higher earnings, and tenure with the firm is only weakly associated with a rise in earnings. Given that we do not observe any screening or involuntary separations in practice, this modestly rising wage profile likely reflects self-selection and rising productivity more than screening.

Shocks.-The patterns we observe could reflect attempts to smooth consumption in response to shocks or changing needs by changing labor allocation, such as in models of added worker effects and other labor market responses to shocks (Morduch 1995).

It is worth noting that nearly all of the applicants we interviewed described industrial jobs as temporary in the sense that they did not expect to work there for more than a few years. For example, women commonly explained that they planned to work in the formal sector for only a few years, until they had children and took on

\footnotetext{
${ }^{48}$ Indeed, even the authors succumbed to this money illusion, initially failing to keep survey enumerator wages in pace with inflation until a correction was made after high quit rates and complaints.
} 
child-rearing, household occupations, and more flexible part-time self-employment. Many young people, perhaps even a majority, also expressed a preference for one day running their own businesses. Formal sector jobs were temporary jobs while they accumulated enough savings to start an enterprise. Among those who did see a career in the formal sector, they commonly saw the factory as a stepping stone to white-collar or other nonindustrial employment. These patterns are largely consistent with recent labor market studies and ethnographic work in Ethiopia, which find that higher paid white collar jobs are preferred and that roughly half of factory workers are dissatisfied with their job (Mains 2012, Franklin 2017). Recent panel studies of young adults with some secondary education suggest that young people typically take temporary, often unsatisfactory work, in different places, varying from week to week. Few can afford to be completely unemployed for long stretches, and rely on family networks for short periods before returning to some temporary work, all while searching for higher quality permanent jobs. Both this survey and ethnographies of youth and work in Ethiopia stress how longer-term, contractual jobs are prized, especially white-collar jobs in the private and public sector (Mains 2012). Industrial jobs of the kind we studied appear to belong in the undesirable rather than the desirable category.

This does not explain the often very short tenure of most of the people offered a job in a study firm, however, especially since quitters often exited the industrial sector entirely. Unfortunately we do not have data on pre-application shocks, nor do we have sufficiently detailed employment histories to distinguish new entrants from recently or long-term unemployed. Even if we did, unobserved selection into the experimental sample would cloud any test. ${ }^{49}$ Hence, sharp tests of the shocks hypothesis are not possible. Nonetheless, there is some evidence consistent with industrial jobs as a response to temporary shocks.

First, in interviews, some applicants described the factory jobs as undesirable and short-term occupations while they found more interesting, respectable, or easier work for better wages. In these accounts, they seemingly understood the poor conditions, difficulty, and low pay of industrial work, but endured it for a few weeks or months between other, better jobs.

Similarly, a 2012 urban labor market survey found that young workers, especially the higher-ability and more ambitious ones, churn through multiple jobs, treating them as temporary places to earn money while they search for something better (Franklin 2017). That is, seasonal or short-term but higher-paying informal work is regularly available, and less desirable jobs (such as industrial work) are used in the interim.

Indeed, as described in Section IV, the average job applicant had other, largely informal employment opportunities that paid similar wages with fewer disamenities. And when the grant was offered, giving people marginally more earnings in informal self-employment, the percentage of people working in an any industrial job at endline halved, from 20 percent in the control group to 9 percent in the entrepreneurship arm.

\footnotetext{
${ }^{49}$ For instance, we cannot easily distinguish between an adverse shock due to chance or unobserved characteristics of the worker, such as motivation and other factors that affect outside options.
} 
Not all the evidence is consistent with this view, however. If shocks are influential, we might expect applicants with more liquid wealth to leave more quickly. But we see no heterogeneity in length of stay in the industrial job by baseline household assets (see online Appendix X.J). Moreover, people commonly quit despite having no other full-time work opportunity, instead entering a spell of unemployment. As young people who commonly lived with their parents or a husband, they did not necessarily need to work full-time, and given the low wage and demanding work many said they preferred to stop working full-time and do petty jobs while searching for better fulltime employment. This is a common employment search strategy in Ethiopia. Hence, shocks are probably only a partial explanation for the short tenure we observe.

Learning and Matching.- The final possibility is akin to the imperfect information and matching case of Jovanovic (1979), but in this case the workers are the ones learning about the job. That is, a job is an "experience good," in that its full characteristics are only revealed to the worker when taking it on. While workers know the wage in advance, they do not know the nonwage characteristics, including how hard they have to work, the working conditions, and other features (Nelson 1970). As our sample is young and has little formal labor market experience, and since the sector is fairly young, applicants may not know their affinity for the work or the risks or disamenities in advance, and so they learn by doing. They quit if they discover the job was a poor match for them given wage levels and their opportunity cost. Recent models include Antonovics and Golan (2012), Papageorgiou (2014), and Gervais et al. (2014).

Again, due to unobserved selection into the sample, it is not possible to test this interpretation formally. ${ }^{50}$ However, the qualitative data, along with labor market surveys, are consistent with this theory. For 81 percent of applicants, this was their first industrial job (indeed, for most it was their first formal sector job). We do not have data on pre-application expectations of the posts. But in both exit and qualitative interviews, some people reported they had little sense of the nature or difficulty of the work, or the hazards involved a priori. ${ }^{51}$

Other applicants did say they had some information about the quality of the jobs in advance, from friends and neighbors, and that they expected the jobs to be unpleasant. But they said they underestimated the disamenities, or how little the pay was once they factored in the inflexibility of the work, transport time and costs, or the physical demands and risks. In both cases, they tried out the job but left if the workload and disamenities were not worth their expectations for such work. Similar points are echoed by subjects in a weekly panel survey of young job searchers in the capital over the course of a year (Franklin 2017).

Finally, recall that quitters did not not simply switch industrial jobs. Rather, they tended to exit the industrial sector entirely, suggesting they realized their poor fit.

\footnotetext{
${ }^{50}$ For instance, it's not clear what we should predict if an applicant had prior industrial experience. Should they stay a shorter time because they learn more quickly? Or are they a good match for unobserved reasons and are likely to stay?

${ }^{51}$ Applicants with prior industrial experience should have some sense of the job. Yet in online Appendix IV.I, we see that prior industrial experience was associated with lower endline earnings and higher turnover. Rather than being better matches, these could be people who were poor matches with industrial jobs who took the work because of adverse shocks. It is such a self-selected sample, we hesitate to infer much from the patterns.
} 
Hence, there is suggestive evidence for learning and matching on the part of workers contributing to the high turnover rates observed.

\section{B. Generalizability}

If we want to extrapolate to the case of Ethiopia, it is important to note our five firms were largely domestically and foreign-owned exporters, sought out low-skilled and inexperienced employees, and paid below average wages, but not wages that were exceptionally low for firms in these particular labor-intensive sectors. In this light, at best we have estimated local average treatment effects on young, entry-level workers to firms with a large number of lower-skilled jobs where employees are, in practice, interchangeable, and the labor market is not evidently segmented. They are in firms in sectors attracting considerable FDI, and seen as a future for this country and its labor force.

Clearly there are limits to what we can learn from five firms. It's conceivable that industrial labor markets in other countries, or higher-skill industries, are more segmented. Even so, it's worth noting that the patterns we observe-low wages and high rates of turnover-have been relatively common features of industrial jobs from modern day higher skill Chinese manufacturing to industrialization in the United States or United Kingdom as recently as a century ago. Hence, our firms and worker experiences may not be so exceptional.

For instance, one study of turnover at an Apple supplier in eastern China found that 92 percent of workers leave within six months of hire, and weekly rates of exit average about 7 percent. ${ }^{52}$ Another example comes from Jordan, where Groh et al. (2014) not only shows that it is difficult to create matches between employers and workers searching for work, but that a majority of workers quit their "successful matches" within a few months. It's not clear whether these represent churn across sectors or within the industrial sector, and within-sector churn is undoubtedly part of the activity.

There is substantial historical evidence of cross-sector churn and industrial exit in the West. For instance, Beckert (2014), looking at early textile development, found high turnover and exit to be the norm from Barcelona to Liverpool to New England. For example, he writes:

The Dover Manufacturing Company in Dover, New Hampshire, had to employ a total of 342 workers in the period from August 1823 to Oct. 1824 just to maintain an average workforce of approximately 140. ... Entering the factory for a few weeks, they would leave once they had made enough money to hold them over to the selling of their crops or when their labor was needed on the farm.

Similarly, Montgomery (1989) and Kaufman (2008) note how, between 1900 and 1920, US companies became aware of (and obsessed with) high turnover. In 1913, turnover at Ford Motor Company was 370 percent, and General Electric had

\footnotetext{
${ }^{52}$ A poll of Chinese workers and firms found that over 40 percent of employees stayed at their previous companies for just 1 to 2 years, and only 38 percent of polled firms had prepared strategies to retain their workers even though nearly all said they were aware of the negative impact of turnover (Hays PLC 2012).
} 
turnover rates exceeding 100 percent in its plants. While the revolution in scientific management, or "Taylorism," is often associated with increasing productivity, reducing employee turnover was actually its initial focus. Increased screening was one of the innovations introduced.

The point is that high turnover (within and across sectors) is a historically common feature of manufacturing. The features of our Ethiopian case-low industrial wages and high sectoral turnover-could be influenced by the fact that the country is still at an early stage of industrialization, with relatively few manufacturers competing for workers. Low wages and high turnover could also be driven by poor personnel management. The story of US manufacturing above is one of innovation in management practice. Ethiopian firms may have yet to adopt and adapt these innovations.

To answer the question of generalizability requires replication, especially in countries at different stages of industrialization, or where the degree of industrialization and competition for labor varies over time. The openness of so many firms to participate in the study suggests replication elsewhere is possible.

\section{Implications}

However unattractive these jobs are to the majority of workers, we do not conclude that Africa needs fewer low-wage manufacturers. As we saw, these jobs paid more than the alternatives available to a substantial fraction of workers. Moreover, advocates such as Krugman (1997) have argued that poor countries need more sweatshops not because they pay wage premiums, but rather because worker wages should rise as more and more firms begin to compete for an increasingly smaller pool of experienced workers, and as firms begin to adopt more technologically advanced production that is complementary to human capital. If so, wages would rise in general, in the informal as well as formal sector, and we would not expect an experiment such as ours to yield treatment effects on income.

Even so, the adverse health effects suggest an important role for information or regulation, especially if workers face these risks uninformed, or are time-inconsistent in their choices over short-term gains at long-term costs. For instance, the government or firms could begin to offer disability insurance, insist that firms communicate risks more clearly, or identify and limit the use of the most hazardous chemicals.

Regulation, of course, risks raising labor costs and benefiting insiders at the expense of outsiders. An important direction for more research is the costs and benefits of regulation. An important example is Harrison and Scorse (2010), who show that anti-sweatshop activists' campaigns in Indonesia led to large real wage increases in targeted enterprises, with some costs in terms of reduced investment, falling profits, and increased probability of closure for smaller plants, but no adverse employment effects.

Understanding better why firms do not try to combat high turnover, for example through paying efficiency wages, may also lead to better and more efficient outcomes, especially if the low wages being paid are suboptimal. It is possible that formal and informal firms alike are poorly managed, or that the sector is constrained in unobserved ways. But it is also possible that, in very unskilled industries, high 
turnover at very low wages, where workers with the poorest outside options remain, is the profit-maximizing choice. The efficacy of management and the take-up and effectiveness of modern human resource practices in the firm is an important but unexplored area of research.

\section{REFERENCES}

Abadie, Alberto, Matthew M. Chingos, and Martin R. West. 2014. "Endogenous Stratification in Randomized Experiments." National Bureau of Economic Research (NBER) Working Paper 19742.

-Aitken, Brian, Ann Harrison, and Robert E. Lipsey. 1996. "Wages and foreign ownership: A comparative study of Mexico, Venezuela, and the United States." Journal of International Economics 40 (3): 345-71.

Akerlof, George A., and Janet L. Yellen. 1986. Efficiency Wage Models of the Labor Market. Cambridge: Cambridge University Press.

-Anderson, Michael L. 2008. "Multiple Inference and Gender Differences in the Effects of Early Intervention: A Reevaluation of the Abecedarian, Perry Preschool, and Early Training Projects." Journal of the American Statistical Association 103 (484): 1481-95.

-Antonovics, Kate, and Limor Golan. 2012. "Experimentation and Job Choice." Journal of Labor Economics 30 (2): 333-66.

Atkin, David. 2009. "Working for the Future: Female Factory Work and Child Health in Mexico." http://www.mit.edu/ atkin/Women\%20in\%20Manufacturing_old.pdf.

Atkin, David. 2012. "Endogenous Skill Acquisition and Export Manufacturing in Mexico." National Bureau of Economic Research (NBER) Working Paper 18266.

Banerjee, Abhijit V., and Esther Duflo. 2011. Poor Economics: A Radical Rethinking of the Way To Fight Global Poverty. New York: Public Affairs.

Beckert, Sven. 2014. Empire of Cotton: A New History of Global Capitalism. New York: Penguin Random House.

Beegle, Kathleen, Joachim De Weerdt, Jed Friedman, and John Gibson. 2012. "Methods of household consumption measurement through surveys: Experimental results from Tanzania." Journal of Development Economics 98 (1): 3-18.

- Bernard, Andrew B., Raymond Robertson, and Peter K. Schott. 2010. "Is Mexico a Lumpy Country?" Review of International Economics 18 (5): 937-50.

- Bigsten, Arne, Taye Mengistae, and Abebe Shimeles. 2013. "Labor Market Integration in Urban Ethiopia, 1994-2004." Economic Development and Cultural Change 61 (4): 889-931.

Blattman, Christopher, and Stefan Dercon. 2018. "The Impacts of Industrial and Entrepreneurial Work on Income and Health: Experimental Evidence from Ethiopia: Dataset." American Economic Journal: Applied Economics. https://doi.org/10.1257/app.20170173.

Blattman, Christopher, and Laura Ralston. 2015. "Generating employment in poor and fragile states: A review of the evidence from labor market and entrepreneurship programs." https://www.povertyactionlab.org/sites/default/files/publications/Blattman_Employment\%20Lit\%20Review.pdf.

-Card, David. 1996. "The Effect of Unions on the Structure of Wages: A Longitudinal Analysis." Econometrica 64 (4): 957-79.

- Casey, Katherine, Rachel Glennerster, and Edward Miguel. 2012. "Reshaping Institutions: Evidence on Aid Impacts Using a Pre-Analysis Plan.” Quarterly Journal of Economics 127 (4): 1755-1812.

Central Statistical Authority (CSA). 2011. Large and Medium Manufacturing Industries Survey 2009_ 2010. Addis Ababa, Ethiopia: Government of Ethiopia Ministry of Finance and Economic Development.

Economist. 2014. "An Awakening Giant: Manufacturing in Africa." February 8. https://www.econo$\mathrm{mist} . c 0 \mathrm{~m} / \mathrm{news} / \mathrm{middle}$-east-and-africa/21595949-if-africas-economies-are-take-africans-willhave-start-making-lot.

-El Badaoui, Eliane, Eric Strobl, and Frank Walsh. 2008. "Is There an Informal Employment Wage Penalty? Evidence from South Africa.” Economic Development and Cultural Change 56 (3): 683710.

-Fields, Gary S. 1975. "Rural-urban migration, urban unemployment and underemployment, and jobsearch activity in LDCs." Journal of Development Economics 2 (2): 165-87.

Franklin, Simon. 2015. "Location, Search Costs and Youth Unemployment: A randomized trial of transport subsidies in Ethiopia." Centre for the Study of African Economies (CSAE) Working Paper 2015-11. 
Franklin, Simon. 2017. "Location, search costs and youth unemployment: Experiment Evidence from Transport Subsidies." Economic Journal. https://doi.org/10.1111/ecoj.12509.

Gervais, Martin, Nir Jaimovich, Henry E. Siu, and Yaniv Yedid-Levi. 2014. "What Should I Be When I Grow Up? Occupations and Unemployment over the Life Cycle." National Bureau of Economic Research (NBER) Working Paper 20628.

Getahun, Tigabu D., and Espen Villanger. 2016. "Labor-intensive jobs for women and development: Intrahousehold welfare effects and its transmission channels." Chr. Michelsen Institute (CMI) Working Paper 2015:15.

Groh, Matthew, David McKenzie, Nour Shammout, and Tara Vishwanath. 2014. "Testing the Importance of Search Frictions, Matching, and Reservation Prestige through Randomized Experiments in Jordan.” World Bank Policy Research Working Paper 7030.

Harris, John R., and Michael P. Todaro. 1970. "Migration, Unemployment and Development: A Two-Sector Analysis." American Economic Review 60 (1): 126-42.

-Harrison, Ann, and Jason Scorse. 2010. "Multinationals and Anti-Sweatshop Activism." American Economic Review 100 (1): 247-73.

Hays PLC. 2012. "Retention: Is It Getting Enough Attention?" https://www.hays.cn/cs/groups/hays_ common/@cn/@content/documents/digitalasset/hays_088412.pdf.

Heath, Rachel, and A. Mushfiq Mobarak. 2014. "Manufacturing Growth and the Lives of Bangladeshi Women.” National Bureau of Economic Research (NBER) Working Paper 20383.

Hewett, P., and S. Amin. 2000. Assessing the Impact of Garment Work on Quality of Life Measures. Dhaka, Bangladesh: Bangladesh Institute of Development Studies.

-Jovanovic, Boyan. 1979. "Job Matching and the Theory of Turnover." Journal of Political Economy 87 (5): 972-90.

Kabeer, Naila. 2000. The Power to Choose: Bangladeshi Women and Labour Market Decisions in London and Dhaka. London: Verso.

- Kahneman, Daniel, and Angus Deaton. 2010. "High income improves evaluation of life but not emotional well-being." Proceedings of the National Academy of Sciences 107 (38): 16489-93.

-Katz, Lawrence F., Lawrence H. Summers, Robert E. Hall, Charles L. Schultze, and Robert H. Topel. 1989. "Industry Rents: Evidence and Implications." Brookings Papers on Economic Activity (Microeconomics) 19: 209-90.

Kaufman, Bruce E. 2008. Managing the Human Factor: The Early Years of Human Resource Management in American Industry. Ithaca: Cornell University Press.

Kling, Jeffrey R., Jeffrey B. Liebman, and Lawrence F. Katz. 2007. "Experimental Analysis of Neighborhood Effects." Econometrica 75 (1): 83-119.

Krugman, Paul. 1997. "In Praise of Cheap Labor." Slate, March 21. http://www.slate.com/business/2018/02/why-rising-wages-scare-the-heck-out-of-stock-market-investors.html.

-Lewis, W. Arthur. 1954. "Economic Development with Unlimited Supplies of Labor." Manchester School 22 (2): 139-91.

-Lipsey, Robert E., and Fredrik Sjöholm. 2004. "Foreign direct investment, education and wages in Indonesian manufacturing." Journal of Development Economics 73 (1): 415-22.

Mains, Daniel. 2012. Hope is Cut: Youth, Unemployment, and the Future in Urban Ethiopia. Philadelphia: Temple University Press.

Martin, Alexandra, Winfried Rief, Antje Klaiberg, and Elmar Braehler. 2006. "Validity of the Brief Patient Health Questionnaire Mood Scale (PHQ-9) in the general population." General Hospital Psychiatry 28 (1): 71-77.

-McKenzie, David. 2012. "Beyond baseline and follow-up: The case for more T in experiments." Journal of Development Economics 99 (2): 210-21.

Montgomery, David. 1989. The Fall of the House of Labor: The Workplace, the State, and American Labor Activism, 1865-1925. Cambridge: Cambridge University Press.

-Morduch, Jonathan. 1995. "Income Smoothing and Consumption Smoothing." Journal of Economic Perspectives 9 (3): 103-14.

- Nelson, Phillip. 1970. "Information and Consumer Behavior." Journal of Political Economy 78 (2): 311-29.

NPR. 2014. "The Next Shirt You Buy May Say 'Made In Ethiopia.' Here's Why.” October 28. https:// www.npr.org/2014/10/28/359655632/the-next-shirt-you-buy-may-say-made-in-ethiopia-hereswhy.

Papageorgiou, Theodore. 2014. "Learning Your Comparative Advantages." Review of Economic Studies 81 (3): 1263-95.

Robinson, Joan. 1962. Economic Philosophy. Piscataway, NJ: Transaction Publishers. 
Rosenzweig, Mark R. 1988. "Labor markets in low income countries." In Handbook of Development Economics, Vol. 1, edited by Hollis Chenery and T. N. Srinivasan, 713-62. Amsterdam: North-Holland.

Scholars Against Sweatshop Labor (SASL). 2001. Scholars Against Sweatshop Labor Statement. Scholars Against Sweatshop Labor Steering Committee. Amherst, MA, October. http://web. archive.org/web/20060207061631/http:/www.umass.edu:80/peri/sasl/petition.htm.

-Söderbom, Mäns, and Francis Teal. 2004. "Size and efficiency in African manufacturing firms: Evidence from firm-level panel data." Journal of Development Economics 73 (1): 369-94.

-Spitzer, Robert L., Kurt Kroenke, Janet B. Williams, and Bernd Löwe. 2006. "A Brief Measure for Assessing Generalized Anxiety Disorder: The GAD-7.” Archives of Internal Medicine 166 (10): 1092-97.

Strauss, John, and Duncan Thomas. 2007. "Health over the Life Course." In Handbook of Development Economics, Vol. 4, edited by T. Paul Schultz and John A. Strauss, 3375-3474. Amsterdam: North-Holland.

Strobl, Eric, and Robert Thornton. 2004. "Do Large Employers Pay More in Developing Countries? The Case of Five African Countries." Journal of Economic Development 29 (1): 137-61.

Verhoogen, Eric A. 2008. "Trade, Quality Upgrading, and Wage Inequality in the Mexican Manufacturing Sector." Quarterly Journal of Economics 123 (2): 489-530.

Ware, John E., Jr., Robert H. Brook, Allyson Davies-Avery, Kathleen N. Williams, Anita L. Stewart, William H. Rogers, Cathy A. Donald, et al. 1980. Conceptualization and Measurement of Health for Adults in the Health Insurance Study: Volume I, Model of Health and Methodology. RAND. Santa Monica, May.

Westfall, Peter H., and S. Stanley Young. 1993. Resampling-Based Multiple Testing: Examples and Methods for p-value Adjustment. New York: John Wiley and Sons.

World Bank. 2015. World Development Indicators 2015. Washington, DC: World Bank. 